\title{
Hot Fuel Examination Facility - The Evolution of a National Asset
}

\author{
Richard S. Wisner
}

December 2010

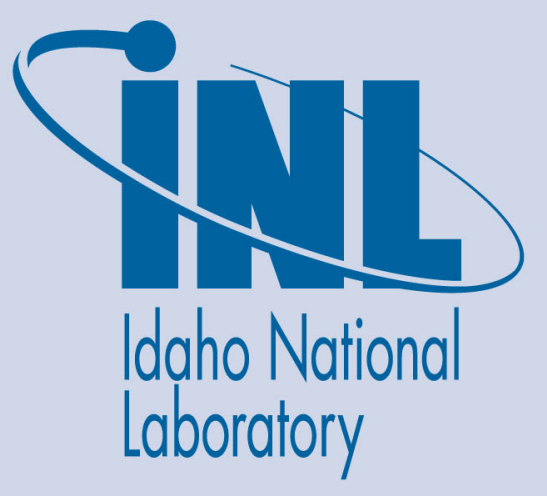

The INL is a U.S. Department of Energy National Laboratory operated by Battelle Energy Alliance 


\title{
Hot Fuel Examination Facility - The Evolution of a National Asset
}

\author{
Richard S. Wisner \\ December 2010 \\ Idaho National Laboratory \\ Idaho Falls, Idaho 83415 \\ http://www.inl.gov \\ Prepared for the \\ U.S. Department of Energy \\ Under DOE Idaho Operations Office \\ Contract Unknown
}




\section{Hot Fuel Examination Facility}

The Evolution of a National Asset

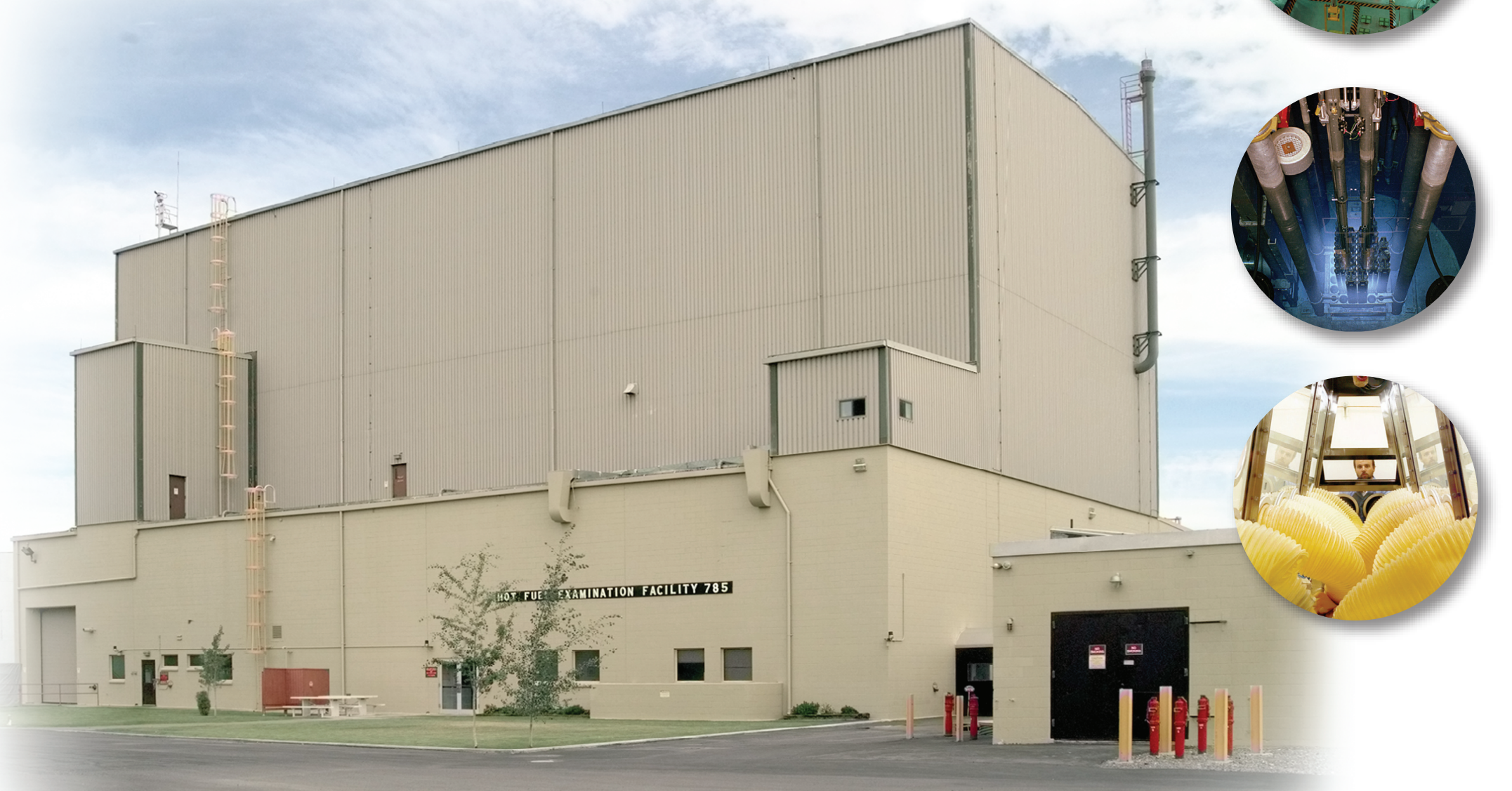





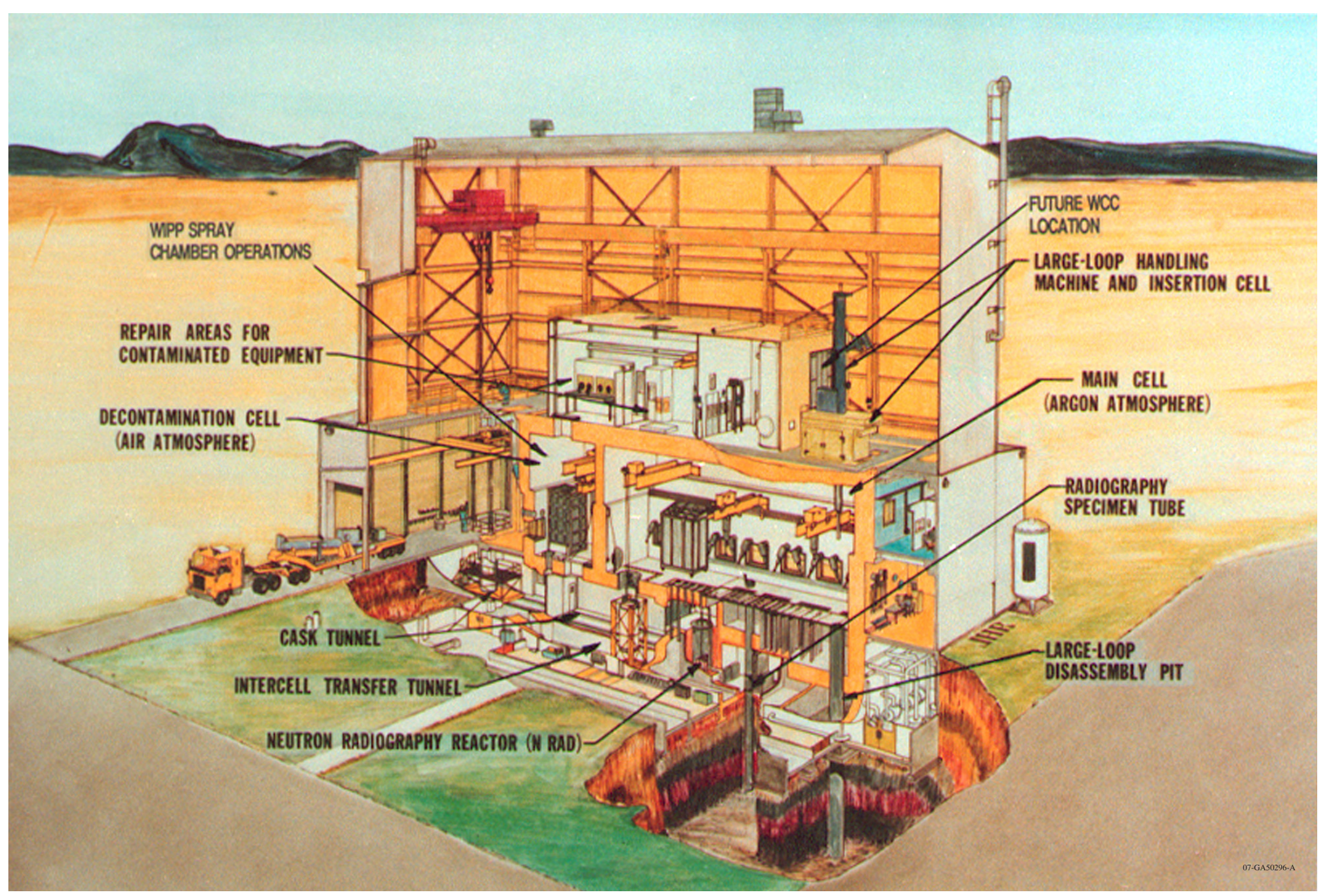

The Hot Fuel Examination Facility (HFEF) 


\section{Contents}

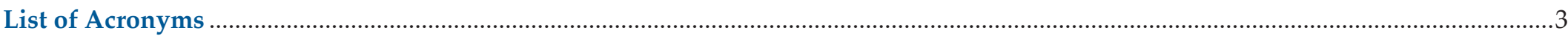

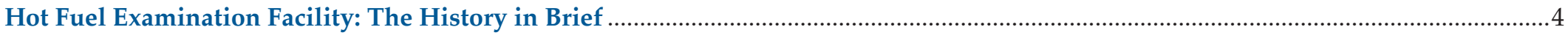

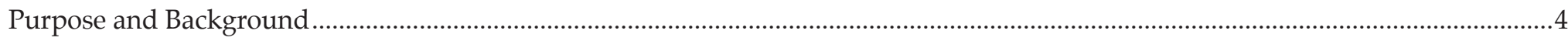

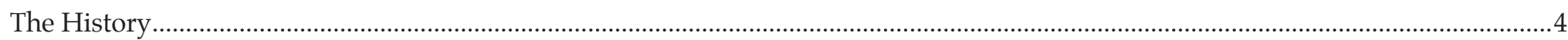

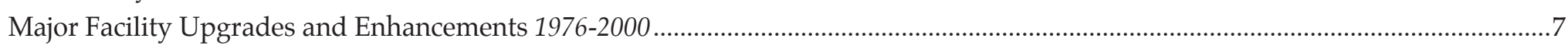

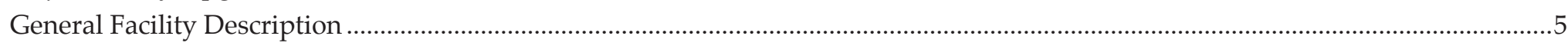

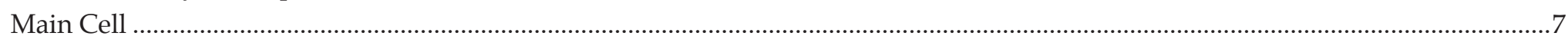

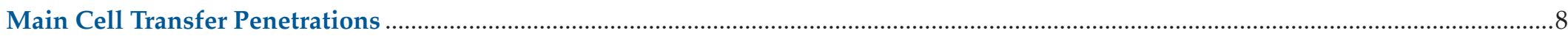

Material Transfers

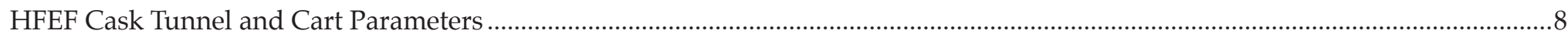

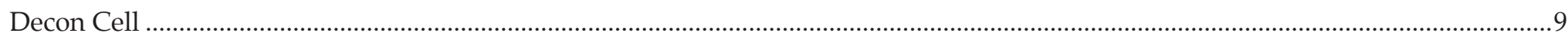

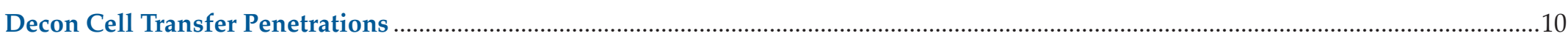

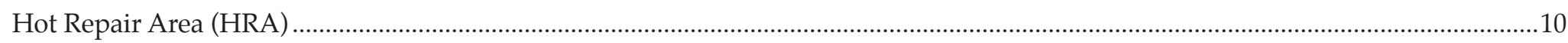

Waste Characterization Area (WCA) ....................................................................................................................................

Waste Form Development: Spent Fuel Demonstration Project, Treatment of Spent Sodium Bonded Nuclear Fuel ..................................14

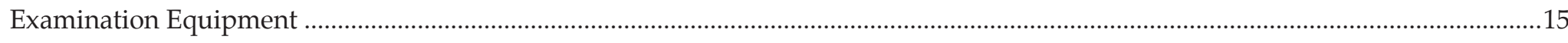

Non-Destructive Examination Equipment.

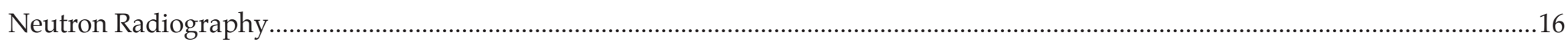

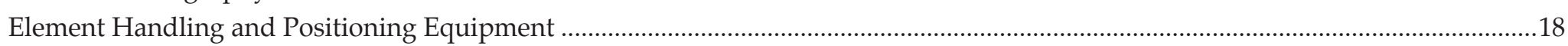

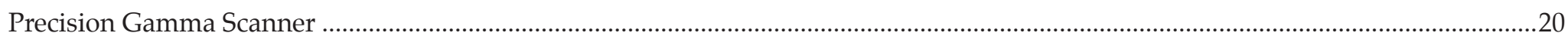

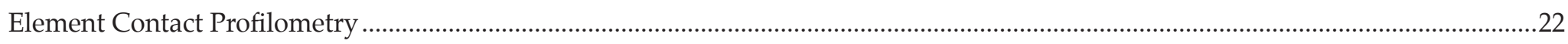

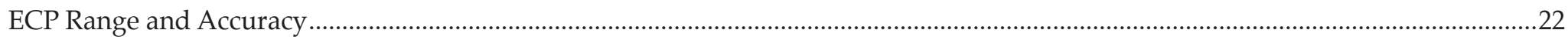

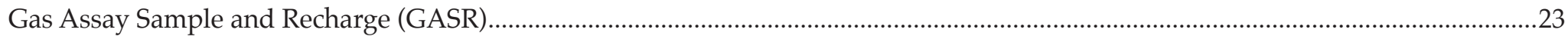

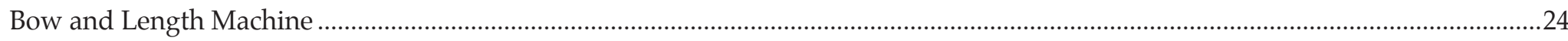

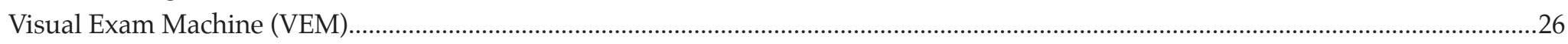

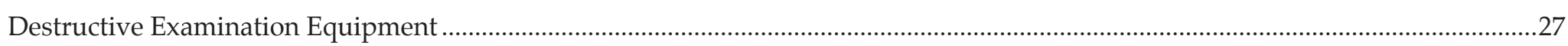

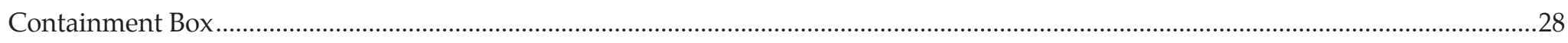

Metallographic Loading Box, Leitz Metallograph and Amray Scanning Electron Microscope ............................................................28

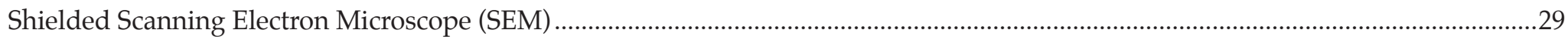

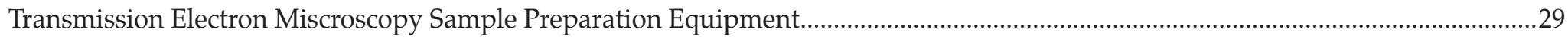

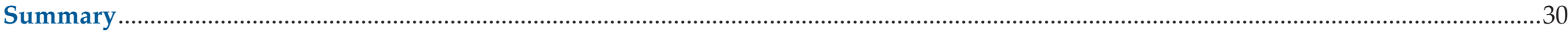

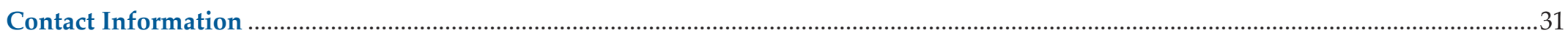




\section{List of Acronyms}

\begin{tabular}{|c|c|c|c|}
\hline ANL & Argonne National Laboratory & LHM & Loop Handling Machine \\
\hline ANL-W & Argonne National Laboratory - West & LIC & Loop Insertion Cell \\
\hline ATR & Advanced Test Reactor & LMFBR & Liquid Metal Fast Breeder Reactor \\
\hline CH & Contact Handled & LWBR & Light Water Breeder Reactor \\
\hline CLWR & Commercial Light Water Reactor & MS & Master/Slave (referring to a MS manipulator) \\
\hline CRL & Central Research Laboratory & OR & Operations Room \\
\hline DOE & U. S. Department of Energy & PGS & Precision Gamma Scanner \\
\hline EBRII & Experimental Breeder Reactor II & PR & Preparation Room \\
\hline ECP & Element Contact Profilometer & PVC & Polyvinyl Chloride \\
\hline EMM & Electro-Mechanical Manipulator & RIP & Rapid Insertion Port \\
\hline ETR & Engineering Test Reactor & RCRA & Resource Conservation Recovery Act \\
\hline FCF & Fuel Conditioning Facility (HFEF/S) & RWMC & Radioactive Waste Management Complex \\
\hline FFTF & Fast Flux Test Facility & SEM & Scanning Electron Microscope \\
\hline FLIP & Fuel Life Improvement Program & SFPD & Spent Fuel Demonstration Program \\
\hline FTIR & Fourier Transform Infrared Spectrometer & SLSF & Sodium Loop Safety Facility \\
\hline GASR & Gas Assay Sample and Recharge system & SNF & Spent Nuclear Fuel \\
\hline HBA & High Bay Area & SP & Sample Preparation \\
\hline HEDL & Hanford Engineering Development Laboratory & SWL & Safe Working Load \\
\hline HFEF & Hot Fuel Examination Facility & TR & Transfer Room \\
\hline HP & Health Physics & TREAT & Transient Reactor Test Facility \\
\hline HRA & Hot Repair Area & TRIGA & Training Research Isotope General Atomics \\
\hline HRR & Hot Repair Room & TRU & Transuranic waste \\
\hline ICPP & Idaho Chemical Processing Plant & VEM & Visual Exam Machine \\
\hline ID & Inner Diameter & VOCs & Volatile Organic Compounds \\
\hline IFR & Integral Fast Reactor & WCA & Waste Characterization Area \\
\hline INEEL & $\begin{array}{l}\text { Idaho National Engineering and } \\
\text { Environmental Laboratory }\end{array}$ & WCC & Waste Characterization Chamber \\
\hline INL & Idaho National Laboratory & WDAS & Waste Data Acquisition System \\
\hline INTEC & Idaho National Technical and Engineering Center & WIPP & Waste Isolation Pilot Plant \\
\hline
\end{tabular}




\section{Hot Fuel Examination Facility: The History in Brief}

\section{Purpose and Background}

The purpose of this document is to describe for the layman as well as for the interested industry representative the evolution of the Hot Fuel Examination Facility (HFEF) at the Materials and Fuels Complex (MFC). Its current capabilities for characterizing spent nuclear fuels (SNF), experimental, surveillance and other irradiated materials, are described. Pertinent hot cell systems are described in detail along with a summary of their current capabilities.

\section{The History}

The Hot Fuel Examination Facility was designed in the late $60 \mathrm{~s}$, constructed and made operational in the early $70 \mathrm{~s}$, to provide support to the Liquid Metal Fast Breeder Reactor community with post- and interim-irradiation examination capabilities. In the following 25 years HFEF has supported dozens of sponsor organizations, domestic and foreign, in the performance of characterizations of hundreds of fuels and materials irradiation experiments.

Major irradiation programs that were supported required the handling of fuels and materials not just from Argonne National Laboratory's Experimental Breeder Reactor II (EBRII), but also Fast Flux Test Facility, (FFTF), Transient Reactor Test Facility (TREAT), Sodium Loop Safety Facility (SLSF), Advanced Test Reactor (ATR), Shippingport Light Water Breeder Reactor (LWBR), and most recently the Commercial Light Water Reactor (CLWR), Watts Bar-irradiated materials and Spent Nuclear Fuel Dry Cask Storage characterizations. Literally thousands of irradiations tests have undergone examinations at HFEF

Since the first post- and interim-examination activities in 1975, HFEF has been upgraded and has evolved into the multi-program facility that it is today. Major and minor facility modifications have contributed to the array of unique capabilities that HFEF offers to the irradiated materials characterization community.

In the late ' 80 s, Argonne National Laboratory agreed to support the Department of Energy's effort by providing waste characterization services in support of the licensing of the Waste Isolation Pilot Plant (WIPP) in New Mexico. The licensing process is supported by characterizing contact-handled transuranic (CH-TRU) waste and demonstrating proof of the waste categorization process used in the assignment of waste categories to materials in drums of waste destined to go to WIPP. After the initial prototype examinations were performed in the HFEF Decon Cell Spray Chamber, the laboratory designed and installed a series of connected alpha glove boxes. This facility modification is called the WIPP Waste Characterization Area. The unique and innovative design of this facility within a facility has allowed the successful examination and characterization of materials in hundreds of waste-containing drums for the U. S. Department of Energy (DOE) since beginning operations in 1994.

A chronological list of major facility modifications and enhancements appears below, as well as a listing of the examination capabilities available today to sponsors of irradiated fuels and materials in need of secure, qualified, and tested materials characterizations. 


\begin{tabular}{|l|l|l|}
\hline \multicolumn{3}{|c|}{ Major Facility Upgrades and Enhancements 1976-2000 } \\
\hline Upgrade & Date & Purpose \\
\hline Second Truck Lock Door & 1976 & Tractor Trailer Drive-through capability, provides safer, more convenient operations \\
\hline Fixed Air Sampling System & 1976 & $\begin{array}{l}\text { Early detection of alpha activity in concentrations as low as 1x10-15 } \mu \text { Ci/cm3. Trend } \\
\text { effectiveness of contamination control within the facility }\end{array}$ \\
\hline 22.7 Mg (25 ton) Truck Lock Crane Addition & 1978 & Relieve High-bay 45.3 Mg (50 ton) crane conflicts and schedule \\
\hline Examination State Extension & 1985 & Allows examinations of rods up to 10' \\
\hline $\begin{array}{l}\text { Hot Repair Area Expansion and Glovebox Addi- } \\
\text { tions }\end{array}$ & $1977-1979$ & Enhanced capabilities to repair remote systems \\
\hline WIPP Waste Characterization Area (WCA) & 1993 & $\begin{array}{l}\text { Glove boxes and RCRA storage facility installed within HFEF. Enables proof of } \\
\text { Knowledge of Process evaluations in waste categorizations }\end{array}$ \\
\hline North Radiography Station Generator & 1994 & $\begin{array}{l}\text { Perform experiments to support development of non-destructive assay neutron tech- } \\
\text { niques for the characterization of radioactive waste and other fissionable materials }\end{array}$ \\
\hline $\begin{array}{l}\text { Spent Fuel Demonstration Waste Form Develop- } \\
\text { ment Support Equipment }\end{array}$ & $1997-1998$ & $\begin{array}{l}\text { Hot Isostatic Press located in the Decon Cell, Grinder/Classifier, V-mixer, HIP Can } \\
\text { Loading apparatus in Main Cell }\end{array}$ \\
\hline Cask Tunnel Trench expansion & 1998 & Deepens trench to accommodate commercial fuel casks \\
\hline Cask Cart upgrade & 1998 & $\begin{array}{l}\text { Facilitates handling commercial-sized casks up to 30 tons, 17' long and 56” diameter } \\
\text { (NAC-LWT, Fort St. Vrain, etc.) }\end{array}$ \\
\hline Examination Stage Extensions & 1998 & Allows examinations of rods up to 152” long \\
\hline North Radiography Station Neutron Generator & 1998 & Neutron probe of materials for Nondestructive Assay of Fissionable material waste forms \\
\hline
\end{tabular}

\section{General Facility Description}

The HFEF is operated by Battelle Energy Alliance at the Idaho National Laboratory (INL). The HFEF is a large alpha-gamma facility which was designed to remotely characterize highly irradiated fuel and structural materials. The wide range of fuel handling and measurement capabilities at HFEF, coupled with the INL's experience in testing and analyzing fuel behavior make HFEF an ideal facility in which to perform post-irradiation and SNF characterization activities.

HFEF was activated by Argonne in March 1975. Most of HFEF's programs have centered on post-irradiation examinations (i.e. characterization) of fuels and materials irradiated in the Experimental Breeder Reactor II (EBR-II), the Transient Reactor Test Facility (TREAT) at MFC, and the Fast Flux Test Facility (FFTF) at the Hanford Engineering Development Laboratory (HEDL) near Richland, Washington, all in support of the Liquid Metal Fast Breeder Reactor (LMFBR) Program.

Other support work has been performed on designs and materials investigated in the Light Water Breeder Reactor Program, the Light Water Reactor safety program, high level waste vitrification studies, Waste Isolation Pilot Plant (WIPP) test, and the U.S. Air Force and Army among others. 
The Hot Fuel Examination Facility (HFEF) is a multi-program hot cell facility. The facility consists of two adjacent shielded hot cells (the Main and Decon cells), a shielded metallographic loading box, an unshielded Hot Repair Area (HRA) and a Waste Characterization Area (WCA). The building is a three-story structure with a basement support area. The building dimensions are $112 \mathrm{ft}$. wide by $154 \mathrm{ft}$. long, with a 19' x 26' extension to the north, comprising the North Radiography Station.

Large equipment items and shipping casks are moved into and out of HFEF through a truck lock on the west end of the building. The truck lock is $85 \mathrm{ft}$. 8 in. long by $17 \mathrm{ft} .4$ in. wide by $27 \mathrm{ft}$. 6 in. high. Roll-up doors located on each end of the truck lock allow moving transporters into and out of the lock. Each roll-up door is $16 \mathrm{ft}$. high by $14 \mathrm{ft}$. wide. An $8 \mathrm{ft}$. by $8 \mathrm{ft}$. hydraulically-operated hatch is located near the north door. The hatch provides access to the cask tunnel area. A $51 \mathrm{ft}$. long by $10 \mathrm{ft}$. wide (13 ft. wide at the south end) hatch in the ceiling of the truck lock provides access to the high bay area (HBA). A $29.5 \mathrm{ft}$. deep cylindrical pit is located at the north end of the truck lock. The pit is 39 inches in diameter for approximately $17 \mathrm{ft}$. from the top and $12 \mathrm{inches}$ in diameter for the remaining $12.5 \mathrm{ft}$. The pit was designed primarily for handling advanced TREAT tests but can be used for other cask handling.

The HRA and WCA are located in the high bay area The area provides access to the ceiling penetrations in the Main and Decon cells as well as the HRA roof hatch. The high bay is also used as a staging area for the WCA.

Both the high bay and truck lock areas are serviced by bridge cranes. The high bay is serviced by a 40-ton crane with a 5 -ton auxiliary hoist. The high bay crane can also be used to service the truck lock by removing the hatch covers over the truck lock. The truck lock is serviced by its own 25 -ton crane.

All floors in HFEF are serviced by an $8 \mathrm{ft}$. by $10 \mathrm{ft}$. freight elevator with a capacity of $8,000 \mathrm{lbs}$. The freight elevator is located in the south west corner of the building.

\section{HFEF Plan Process Areas and Equipment Locations}

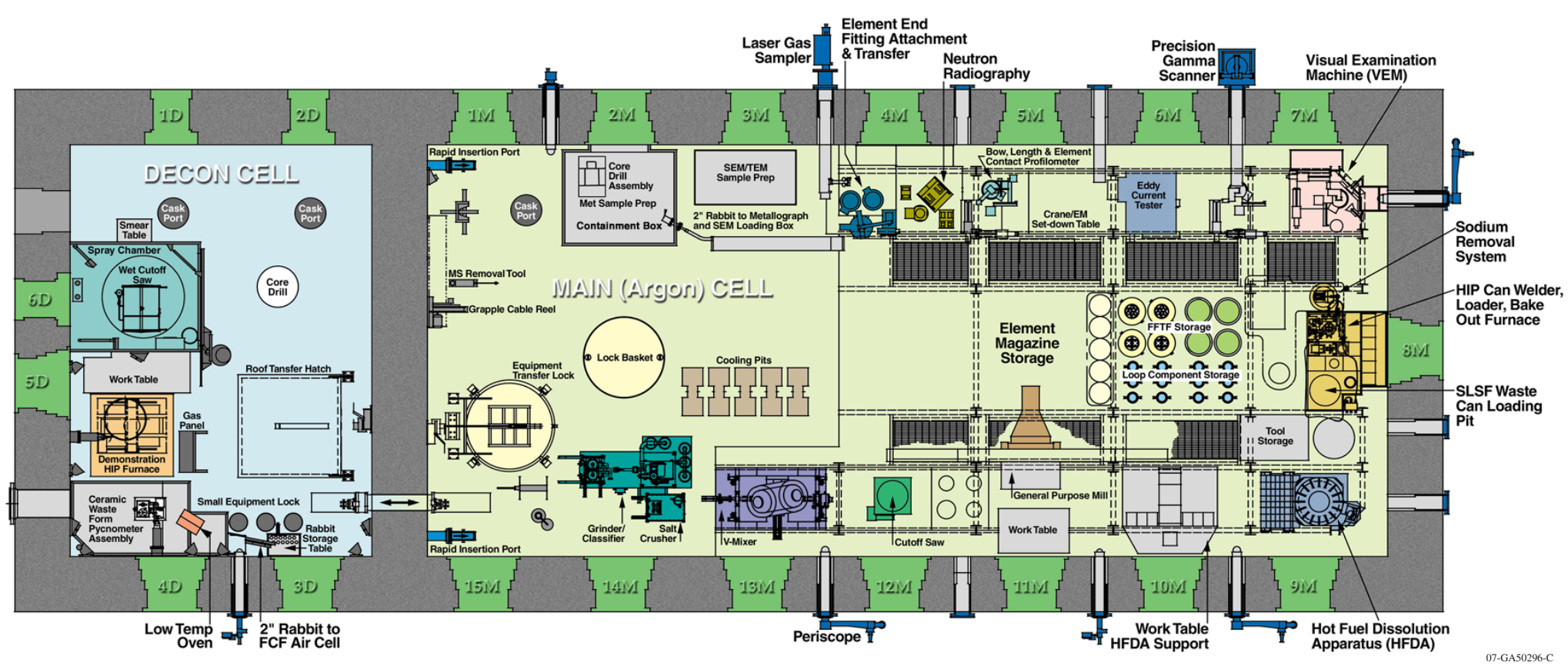




\section{Main Cell}

The HFEF Main cell is $70^{\prime}$ long by $30^{\prime}$ 'wide by $25^{\prime}$ high and has an argon gas atmosphere. Moisture and oxygen levels are maintained about 60 ppm using a purification system, and the maximum oxygen and moisture levels are kept below 100 ppm.

An 8' deep space is located beneath removable flooring and covers the entire width of the cell. The space is used for storage of fuel elements during their examination. Also located in this space are the bases of the examination stages,

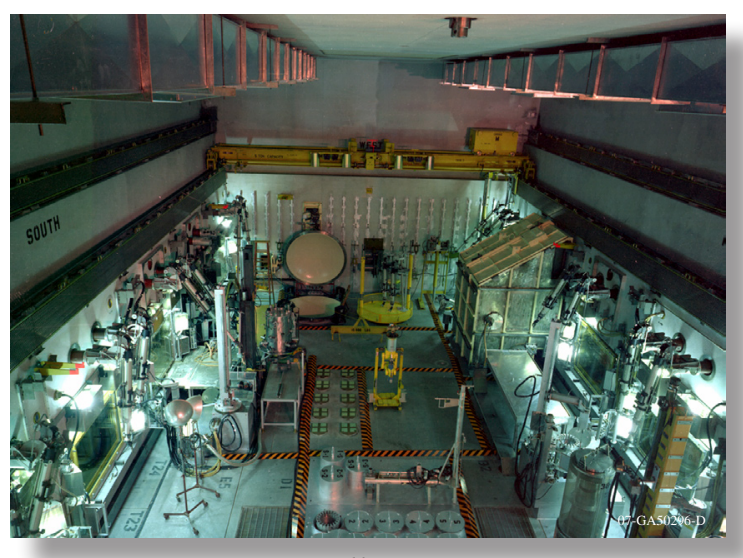

Main Cell View West

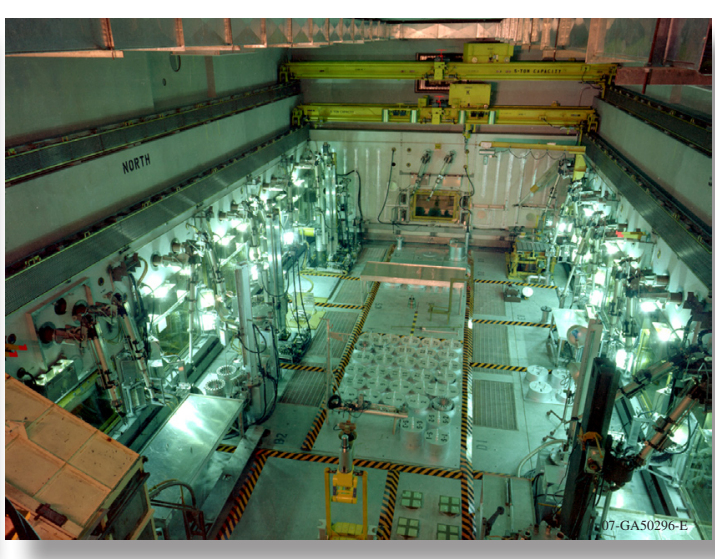

Main Cell View East ducts and filters for the Main Cell cooling system and pits for the storage of radioactive materials. Ten 1' diameter by 10' long storage pipes are located in the center aisle of the cell for storage of EBR-II subassemblies.

In addition to the sub floor space, two 3' diameter pits extend 30' below the level of the removable floor at workstations $8 \mathrm{M}$ and 9M (south-east corner of the cell). These pits are used for storage and handling of long items such as long test loops. Each pit has a corresponding roof penetration so that long items can be transferred into the cell and placed in a pit. Around the pit at workstation $9 \mathrm{M}$ is a machine table for mounting cutters and other equipment used in the disassembly of long loops or items.

The Main Cell is serviced by two electro-mechanical manipulators (EMMs) rated for $750 \mathrm{lb}$ and two 5-ton bridge cranes. The maximum lift for an EMM in the Main Cell is $11 \mathrm{ft} .8 \mathrm{in}$. The maximum lift for a crane in the cell is $19 \mathrm{ft} .115 / 8 \mathrm{in}$.

There are 15 workstations in the Main Cell. Each workstation is equipped with two master/slave (MS) manipulators. Most of the MS manipulators are Central Research Laboratory (CRL) Model J's rated for a 20-lb vertical lift. Five of the workstations are equipped with CRL System 50 manipulators rated for a 50 -lb vertical lift.

The Main Cell is equipped with 7 material transfer penetrations. Only 5 of the penetrations are needed for operations currently. The transfer penetrations and their maximum sizes are listed in the table below.

\begin{tabular}{|l|l|}
\hline Transfer Penetration & Size \\
\hline Large Lock & $6 \mathrm{ft}$. dia by $12 \mathrm{ft}$. long \\
\hline Small Lock & 12 in. wide by 18 in. high by 60 in. long \\
\hline Rapid Insertion Ports (2) & 3 in. dia. by 18 in. long \\
\hline Cask Tunnel Transfer Penetration & $219 / 16$ in. ID \\
\hline Loop Insertion Cell (LIC, Roof Penetration Over 9M) & 25 in. ID \\
\hline Roof Penetration Over 8M (sealed) & 25 in. ID \\
\hline
\end{tabular}




\section{Main Cell Transfer Penetrations}

\section{Material Transfers}

Material transfer means the transfer of radioactive materials from the exterior to the inside of the hot cells. Generally these transfers are made from shipping casks using the cask tunnel and cart. For large shipping casks greater than $17 \mathrm{ft}$. long and greater than 56 in. diameter or greater than 30 tons, the Loop Insertion Cell (LIC) and Main cell roof penetration over workstation 9M are used. Small casks whose weights are less than 5 tons can be handled by transferring them into the Decon cell through the cart room and HRA. Once the cask is in the Decon Cell, it can be unloaded remotely. When transfers are made this way, the cask is wrapped in several layers of plastic to protect from contamination.

All irradiated material transfers begin in the truck lock (see a description of the truck lock under the General Facility Description). Most irradiated material transfers are made through the cask tunnel into either the Main or Decon cells. The maximum weight and dimensions for transferring items through the cask tunnel are listed in the table below.

\begin{tabular}{|l|l|}
\hline Cask Transfer Limitations & Maximum Dimension or Weight \\
\hline Trench Dimensions & 5 '4' wide by $8 \mathrm{ft}$. deep (with deck plate lift mechanisms in bottom) \\
\hline Maximum Cask Length & $17 \mathrm{ft}$. \\
\hline Maximum Cart Load (Cask \& shield ring/tooling/personnel) & 32 tons \\
\hline Maximum Cask Diameter & $56 \mathrm{in.}$ \\
\hline
\end{tabular}

\section{HFEF Cask Tunnel and Cart Parameters}

Because HFEF is an alpha containment facility, special precautions are applied when making transfers between casks and the Main or Decon cells. The casks used to hold the radioactive materials must either be sealed or the materials have to be inside a sealed container. In all cases, the transfers are made through an 8 mil-thick PVC transfer sleeve to prevent the spread of contamination from the cask or cell to the cask tunnel. In order to keep the transfer sleeves from collapsing due to the differential pressure between the cell and cask tunnel, an aluminum funnel is used to mate the cask to the penetration. The funnels used in the penetrations are sized for the operations being performed in that penetration. The Main Cell penetration has an 11.25 in. ID funnel for making transfers between the T-3 cask and the cell. The second or eastern Decon cell penetration has a $12 \mathrm{in.} \mathrm{ID} \mathrm{funnel} \mathrm{for} \mathrm{making} \mathrm{waste} \mathrm{transfers} \mathrm{and}$ for transferring TREAT loops, while the first Decon cell penetration has a $5 \mathrm{in}$. ID funnel for making transfers to and from the T-2 cask. The funnels in each of the penetrations are free to slide up and down in the penetration shielding plugs and can be changed for new operations.

Transfers of large items using large shipping casks are made using the Loop Insertion Cell (LIC) and the corresponding ceiling penetration over workstation 9M. Presently the LIC is sized for the Loop Handling Machine (LHM) used for shipping Sodium Loop Safety Facility (SLSF) loops between the Engineering Test Reactor (ETR) and HFEF. 


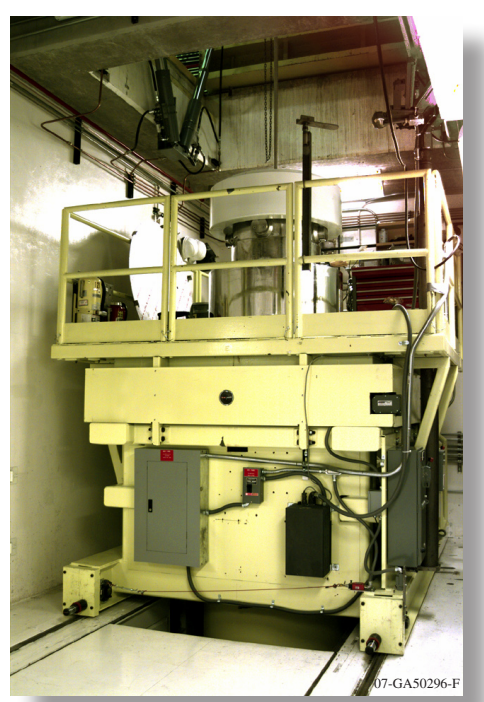

Cask tunnel view of NAC LWT showing Cask in Cask Cart, cask tunnel trench exposed

\section{Decon Cell}

The air-filled Decon cell is adjacent to and communicates with the west end of the Main cell. It is $30 \mathrm{ft}$. wide by $20 \mathrm{ft}$. long by $25 \mathrm{ft}$. high. There is no sub-floor space in the Decon cell, however, there are three $15.5 \mathrm{in}$. diameter by $10 \mathrm{ft}$. deep pits located at workstation 3D. Another similar pit is located at workstation $4 \mathrm{D}$ and a $3 \mathrm{ft}$. diameter by $30 \mathrm{ft}$. deep pit located at workstation $5 \mathrm{D}$.

The Decon cell is equipped with an $8 \mathrm{ft}$. wide by $7 \mathrm{ft}$. deep by $11 \mathrm{ft}$. high spray chamber for decontaminating equipment and non-fissile material using a manipulator-held wand. The wand can be used for spraying either water or steam. A chemical addition tank is connected to the water feed line for the addition of decontamination solutions to the water stream. Items being decontaminated are positioned on a 5 ton turntable inside the chamber so they can be rotated. Both the roof and back side of the spray chamber can be opened remotely so items being decontaminated can be placed inside the chamber.

There are 10 material transfer penetrations and an air-bearing personnel access door in the Decon cell. Only 8 of the penetrations are in use at the present time. The transfer penetrations and their maximum sizes are listed in the table below.

Material handling inside the Decon cell is performed with one $750 \mathrm{lb}$ EMM and one 5 ton crane. The maximum lifting height of the EMM is $11 \mathrm{ft}$.

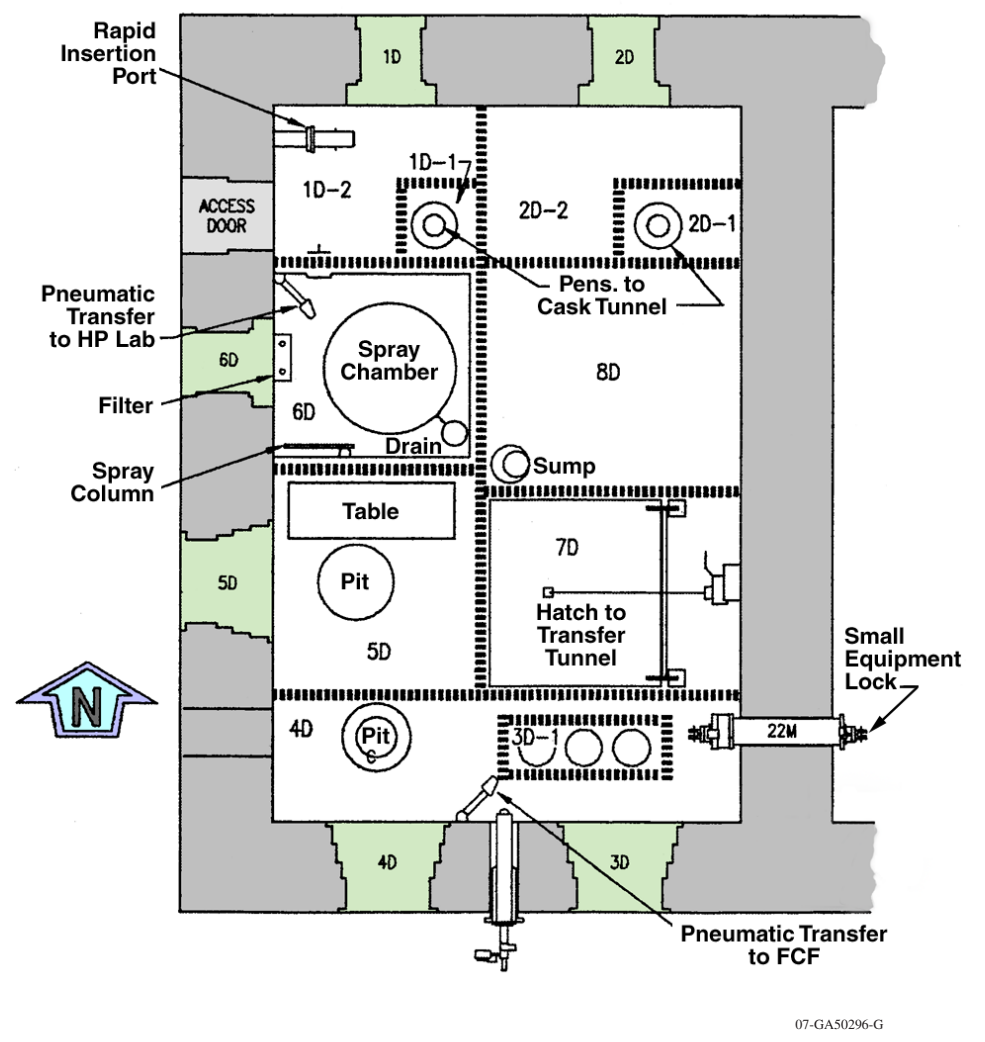


$8 \mathrm{in}$. and that of the crane is $19 \mathrm{ft} .11 \mathrm{in}$. In addition to the EMM and crane, the cell is equipped with 6 sets of MS manipulators. Most of the workstations are equipped with one CRL model E, rated for a $20 \mathrm{lb}$ vertical lift, and one CRL model F rated for a $100 \mathrm{lb}$ vertical lift, MS.

There are two pneumatic transfer stations inside the Decon cell. One station originates at station 4D and runs to the Fuel Conditioning Facility (FCF). The other station originates inside the spray chamber and runs to the radiation safety Health Physics (HP) office . The pneumatic transfer line connecting FCF to HFEF is used for the transfer of small irradiated samples to FCF and the Analytical Laboratory (AL) for analysis.

\begin{tabular}{|l|l|}
\hline Size & $6 \mathrm{ft}$. dia by $12 \mathrm{ft}$. long \\
\hline Large Lock & 12 in. wide by 18 in. high by 60 in. long \\
\hline Small Lock & $219 / 16$ in. ID \\
\hline Two-Cask Tunnel Transfer Penetrations & 3 in. dia. by 18 in. long \\
\hline Rapid Insertion Port & Standard Carrier (“Rabbit”) 2"d x 3.5” \\
\hline Pneumatic Transfer Line to HP Office & Standard Carrier (“Rabbit") 2"d x 3.5” \\
\hline Pneumatic Transfer Line to FCF & $7 \mathrm{ft}$ Square Sliding Door to HRA \\
\hline Decon Cell Roof Hatch & 6 in \\
\hline Ceiling Penetration to HRA & 25 in. ID \\
\hline Sealed Roof Penetration Over 5D &
\end{tabular}

\section{Decon Cell Transfer Penetrations}

\section{Hot Repair Area (HRA)}

The HRA is a complex of rooms located directly above the Decon cell and west end of the Main cell in the high bay area. The outside dimensions of the HRA are $45 \mathrm{ft}$. by $70 \mathrm{ft}$. The primary purpose of the HRA is to perform contact Maintenance on cell equipment. The HRA is comprised of 12 areas:

a. Hot Repair Room

b. Suspect Repair Room

c. Equipment Access Room (Cart Room)

d. Isolation Area Room

e. Survey Room

f. HP Office g. Unsealed Slave Repair Room

h. Bagout Room

i. Sealed Slave Arm Repair Glovebox Room

j. Stepout Area Room

k. Glovewall Room

1. Ancillary Area Room

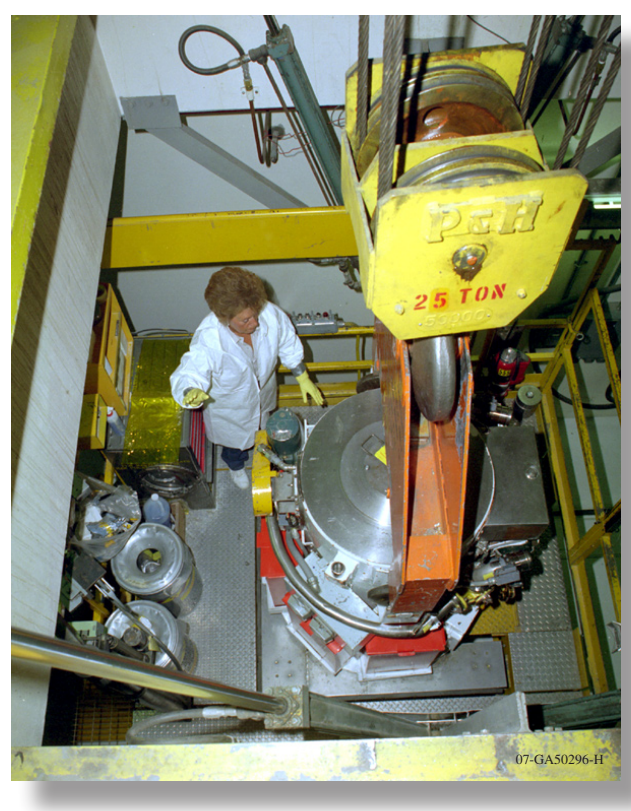


Most of the rooms in the HRA are used specifically for the repair of MS manipulators and other facility specific equipment. The Hot Repair Room (HRR) can be used for the transfer of equipment and materials between the Decon cell and HRA. Both the Hot Repair

and Suspect Repair Rooms are serviced by a 5 ton bridge crane. The crane uses a removable rotating hook enabling remote positioning . With the rotating hook removed the maximum lift inside the repair rooms is $13 \mathrm{ft} .6 \mathrm{in}$. With the hook in place the maximum lift inside the HRR is $12 \mathrm{ft} .1 \mathrm{in}$. The drum on the crane is provided with enough cable for a $50 \mathrm{ft}$. lift so it can be used for raising and lowering equipment into the Decon cell.

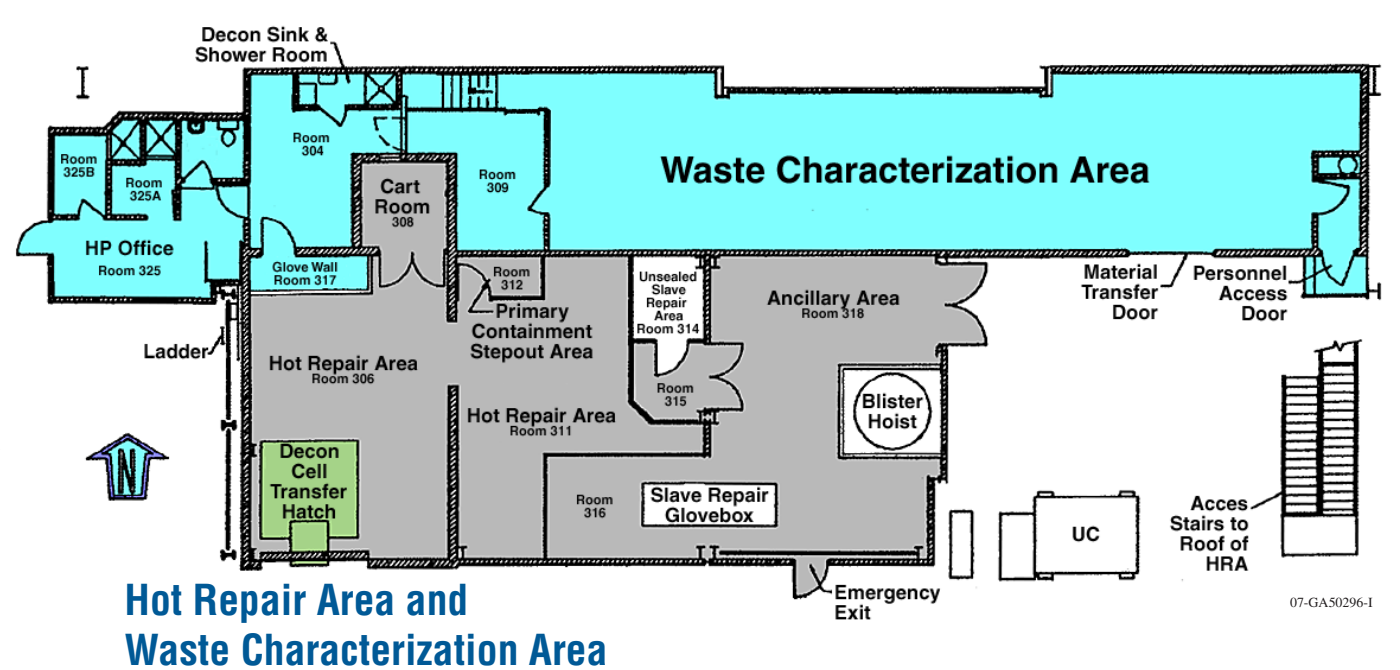

A $10 \mathrm{ft}$. square roof hatch is located in the ceiling of the HRR, directly above the Decon cell roof hatch. The hatch is provided with a $114 \mathrm{in}$. diameter bagging ring so it can be used for the transfer of equipment and material directly from the high bay area into the Decon cell, thus minimizing the risk of spread of contamination.

The equipment access room (cart room) is designed to be a lock in the transfer path between the high bay area and the HRR. The room is $8 \mathrm{ft}$. square by $20 \mathrm{ft}$. high and has a $6 \mathrm{ft}$. $4 \mathrm{in}$. square hatch in the ceiling. The room is generally maintained clean so equipment and materials can be transferred from the high bay area to the room through the hatch. A 5 ton equipment cart runs between the cart room and the HRR for moving the equipment and materials between the cart room and HRR.

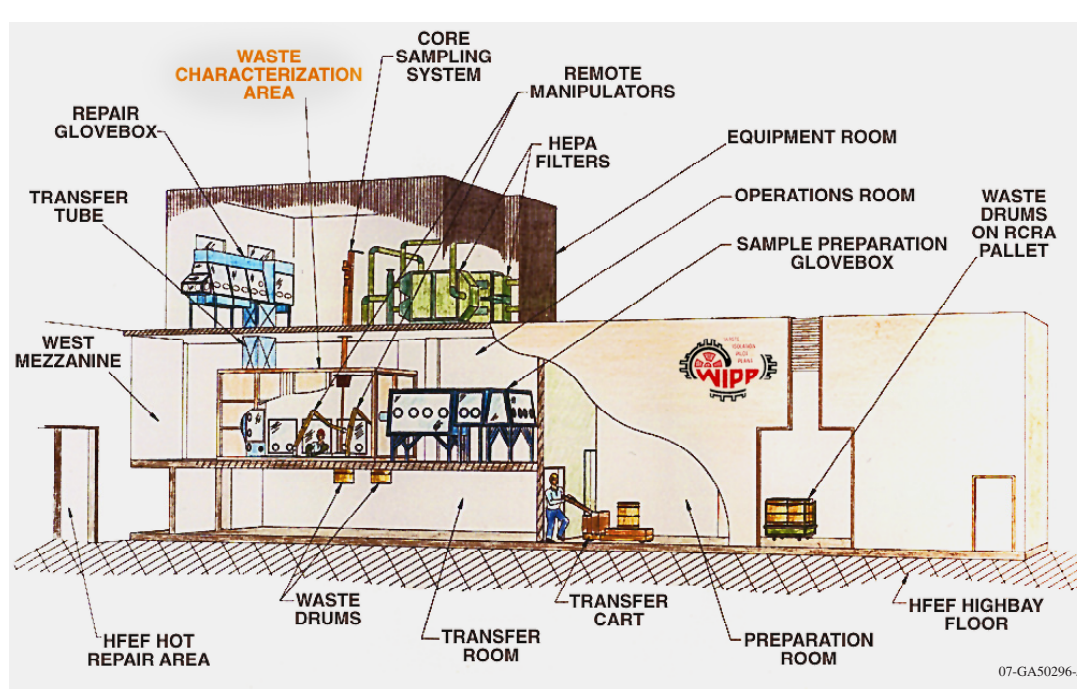

\section{Waste Characterization Area}

The WCA is used for the intrusive characterization and sampling of contact-handled transuranic waste (CH-TRU) for the Waste Isolation Pilot Plant (WIPP) performance assessment. The facility consists of the Preparation Room, Transfer Room, Waste Characterization Chamber (WCC), Sludge Sample Preparation glovebox, Equipment Repair Box, Operations Room and the Equipment Room.

The Preparation Room (PR) is used as a staging area for waste going into and out of the WCC. Waste drums awaiting characterization in the WCC are stored in the PR. Personnel access to the PR is through a vestibule on the south-east corner of the room. Waste drums and equipment are brought into the room using a 5-ton auxiliary hoist on the 40 ton high bay crane through a $10 \mathrm{ft}$. high by $8 \mathrm{ft}$. wide equipment door on the south wall. High bay crane hook access to the room is through a $2 \mathrm{ft}$. wide by $17 \mathrm{ft}$. long rollup door on the vertical wall and ceiling above the equipment door. 


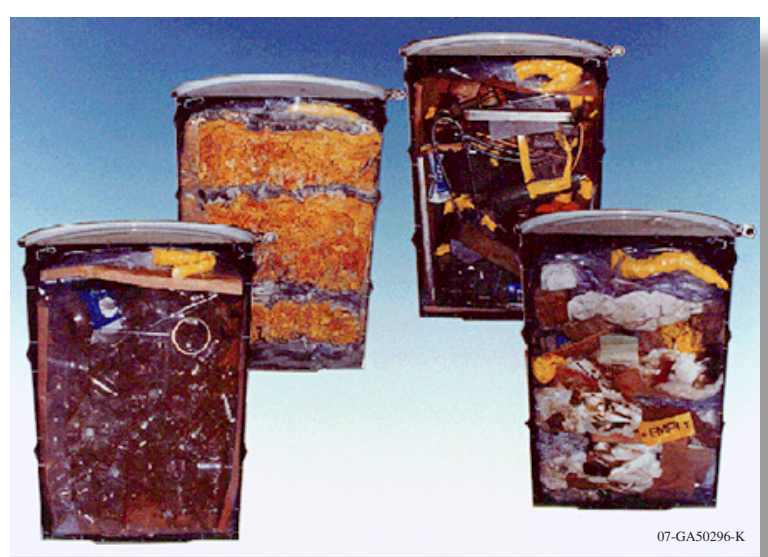

Typical Waste Drum Cross-sectional Views

Waste drums and equipment are handled inside the PR by a cantilever-style jib crane rated for a $4500 \mathrm{lb}$ Safe Working Load (SWL). The crane has a lift height of $12 \mathrm{ft} .8 \mathrm{in}$.

The Transfer Room (TR) is where the waste drums are mated with the Waste

Characterization Chamber (WCC). Access to the room is through double doors from the PR. The drums are moved into and out of the TR using a drum cart rated at 2,000 lb SWL. In addition to moving the drums into and out of the room, the cart is used to raise and lower the drums to the drum ports on the bottom of the WCC. Once the drums are bagged to the WCC, they are held in position in the drum ports by turnbuckles which fasten between the bottom of the WCC and an adapter plate under the drums.

Other equipment in the TR room are; 1) heat sealers for the drum transfer bags, 2) the gas sampling manifold and piping, and 3) a Fourier Transform Infrared Spectrometer (FTIR) for on-line gas analysis. The gas sampling system is used for measuring volatile organic compounds (VOCs), hydrogen and inorganic gases inside the waste drums and bags of waste. The sampling system is computer controlled using pneumatically driven valves on the gas sampling manifold. The manifold also provides connections for taking gas samples of the drum contents.

The WCC is a $16 \mathrm{ft}$. long by $8 \mathrm{ft}$. high by $8 \mathrm{ft}$. deep alpha glovebox used for characterization of CH TRU wastes. The WCC is equipped with shielded viewing windows for personnel protection from low level gamma and beta radiation. Each window is a three piece assembly consisting of an inner safety glass, a .50 in. thick lexan plate and leaded glass on the exterior. There are two $250 \mathrm{lb}$ dual Titan 7F manipulators and a 1,500 lb articulated jib crane for handling the waste and equipment inside the glovebox. A core boring machine is mounted to the top of the glove box over the west drum port and is used for taking samples from sludge drums. There are 28 glove ports on the WCC. These glove ports are located at various heights for waste handling and equipment repair. A transfer port is located on the east end of the WCC for transferring sludge samples to the Sample Preparation glovebox.

The Equipment Room (ER) is located above the WCC and houses the filters, piping and blowers for the WCC ventilation system. In addition to the ventilation equipment, the ER has a Repair Glovebox for repair of the equipment used in the WCC. The glovebox is connected to the west end of the WCC through a transfer tunnel. Equipment is raised and lowered from the Repair Glovebox by a hoist inside the glovebox.
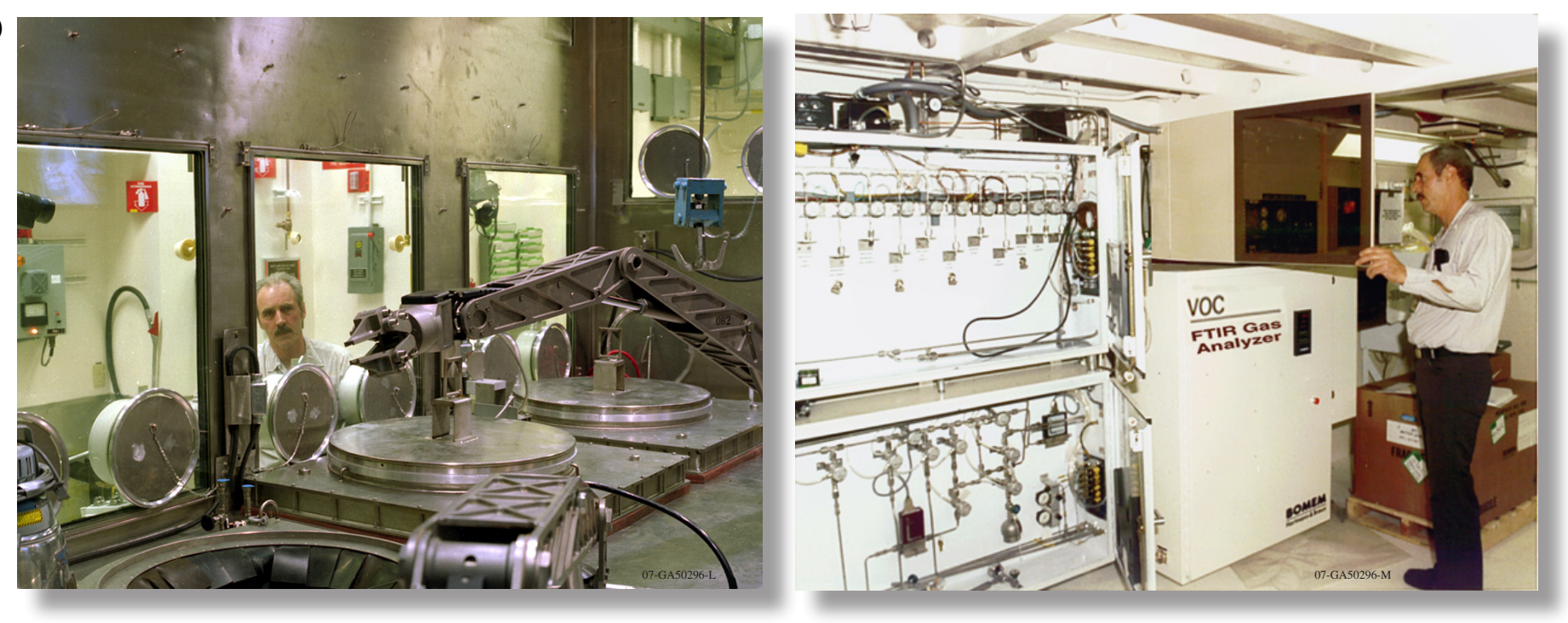
The Operations Room (OR) is the area around the WCC and Sample Preparation and Transfer gloveboxes. The room provides a mezzanine on the west end of the WCC for the Waste Data Acquisition System (WDAS). The WDAS is used for video taping and audio dubbing for documentation of the waste handling operations. A computer controlled switcher is used for switching video sources and recorders. The computer control system for the gas sampling system is mounted on the south end of the WDAS.

In addition to the WDAS, the OR provides monitoring and alarm panels for monitoring the status of the WCA. The panel provides flow and pressure information on the WCC, radiation alarms, breathing air alarms and fire alarms for the inside of the WCC.

The Remote Analytical Sample Preparation (SP) glovebox is used for preparing sludge samples for shipment to the laboratory at Idaho Nuclear Technical and Engineering Center (INTEC) to be analyzed for halogenated volatile organic compounds (VOCs), non-halogenated VOCs, RCRA heavy metals and radioassay. After the sludge has been cored, the core section is transferred to the SP glovebox where the samples are taken at various locations along the core section. As each sample is taken it is weighed, placed in a labeled vial and shipped to INTEC in an approved container. Some experimentation is being done on real time analysis of the samples using X-ray fluorescence.
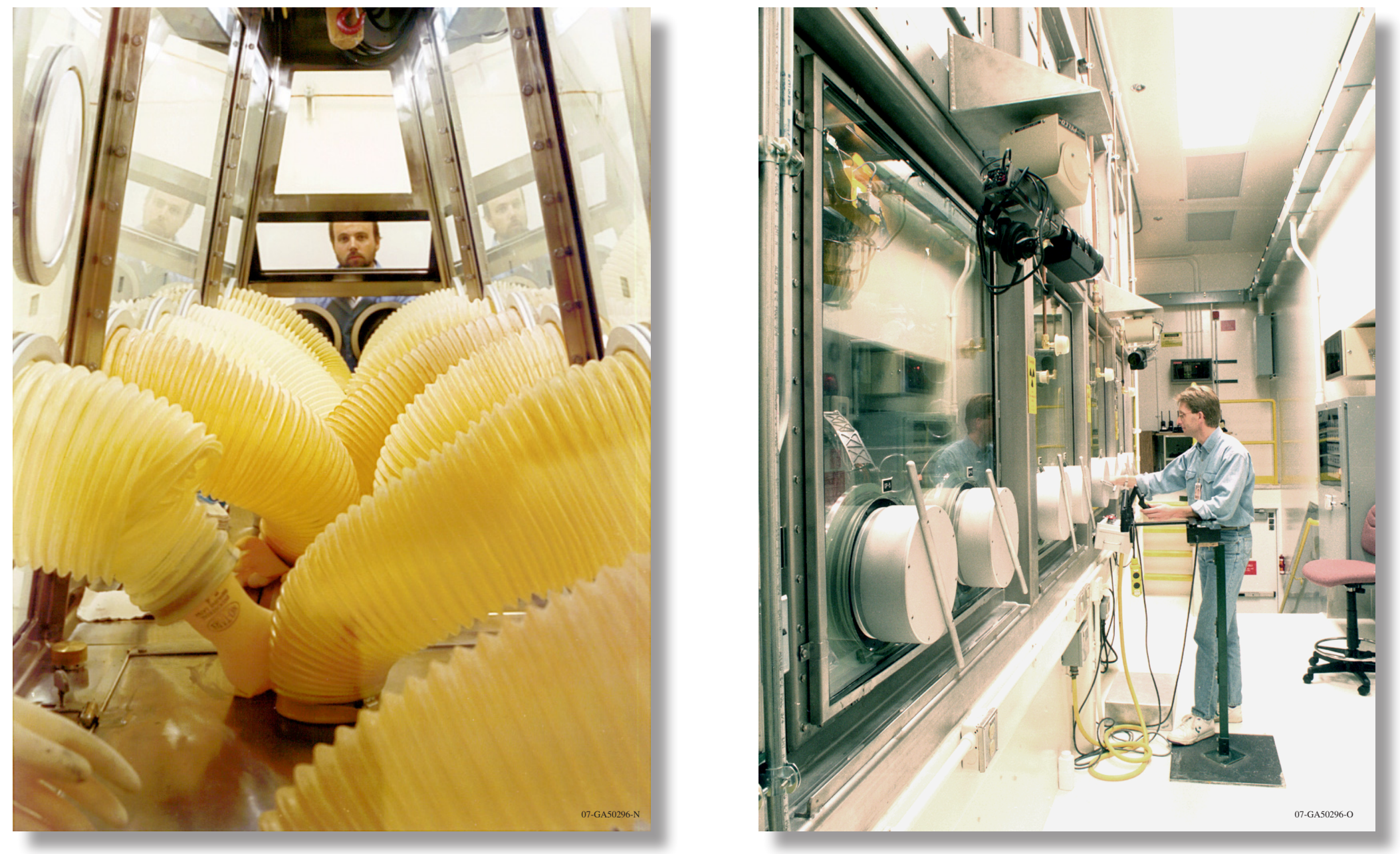


\section{Waste Form Development}

Spent Fuel Demonstration Project, Treatment of Spent Sodium Bonded Nuclear Fuel

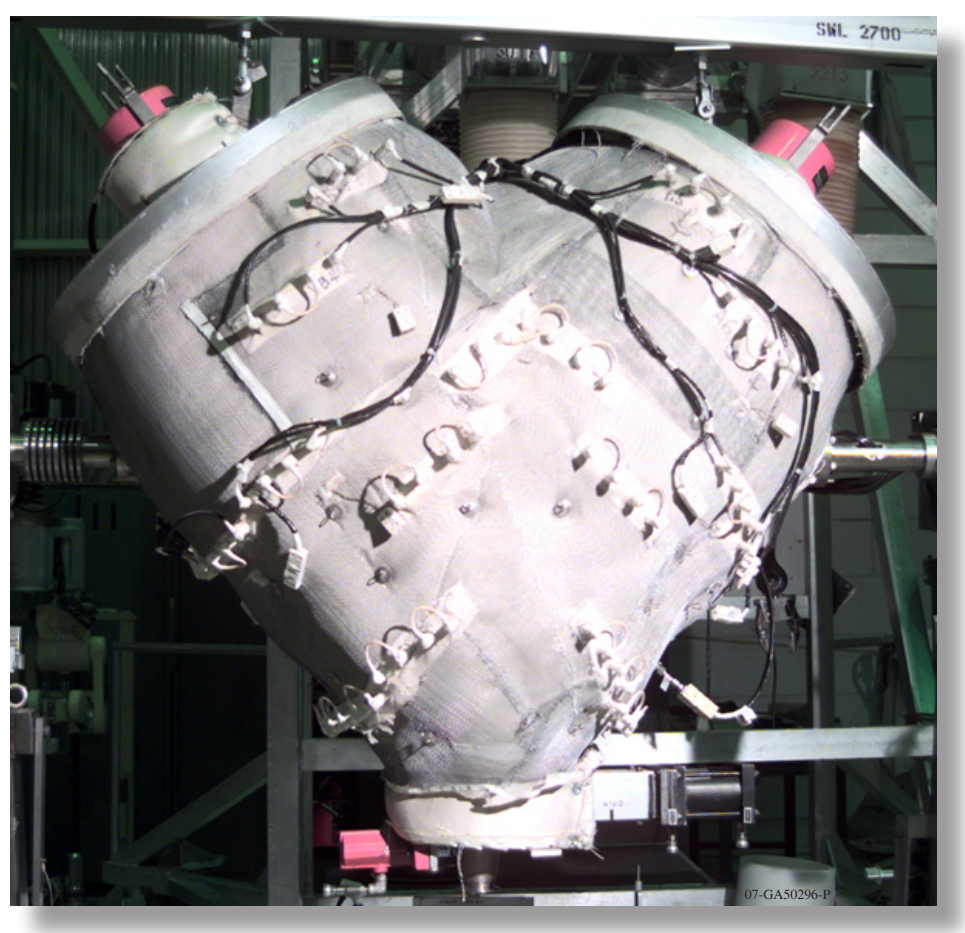

ANL has developed the electrometallurgical process for the treatment of spent nuclear fuel. This Spent Fuel Treatment Program was established to use this technology for treating EBR-II fuel for disposal. Two high level wastes, one ceramic and one metallic, are generated. HFEF participates in the development and characterization of these high-level wastes that are suitable for geological disposal.

In the Main Cell zone $14 \mathrm{M}, \mathrm{LiCl}$ and $\mathrm{KCl}$ eutectic salt laden with fission products of the alkali, alkaline earths, halide, rare earths, and transuranic elements, (the waste by-products of spent fuel treatment operations at FCF), are ground and classified to a particle size range of 75 to $150 \mu \mathrm{m}$. The ground salts are introduced into a V-mixer with crystalline aluminosilicates (zeolites), at window 13M in the Main Cell, and are heated and mixed for 15 hours at $500^{\circ} \mathrm{C}$, nominally. After mixing the ground, classified, fissionproduct laden salts in the presence of zeolite for the pre-determined time and temperature, the mix is allowed to cool and borosilicate glass frit is introduced to the V-mixer and the frit and salt-occluded zeolite are mixed to a homogeneous blend.

After completion of mixing, the frit-zeolite mixture is introduced into intermediate fill containers and transferred to zone $8 \mathrm{M}$ where specially designed containers, HIP cans, are filled, baked out, evacuated and seal-welded shut for processing in the hot isostatic press at window 5D in the Decon Cell. The equipment at $8 \mathrm{M}$ is also being used to test pressureless consolidation, an alternative to HIP processing.

After hot isostatic processing, the HIP can is removed from the HIP and transferred to the adjacent zone, the Decon Cell Spray Chamber. There it is cut transversely in a specially designed cutoff saw. Pieces of the now monolithic ceramic waste are reduced in volume to sample-sized chunks for electron microprobe, ceramography, density measurements, and leach testing to verify the performance of the waste form.

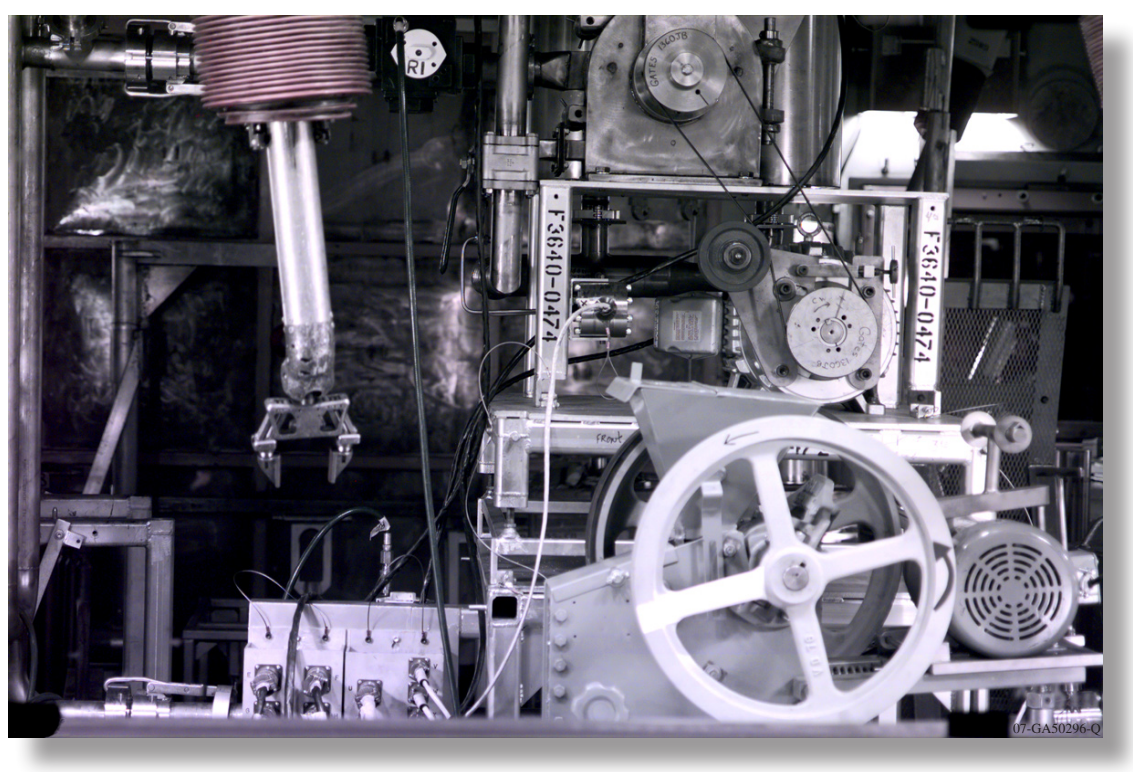




\section{Examination Equipment}

\section{Non-Destructive Examination Equipment}

HFEF was primarily designed as a non-destructive examination facility for cylindrical fuel elements and structural items. The

non-destructive exams that are performed are listed and brief descriptions of

the major non-destructive examination equipment are given below.

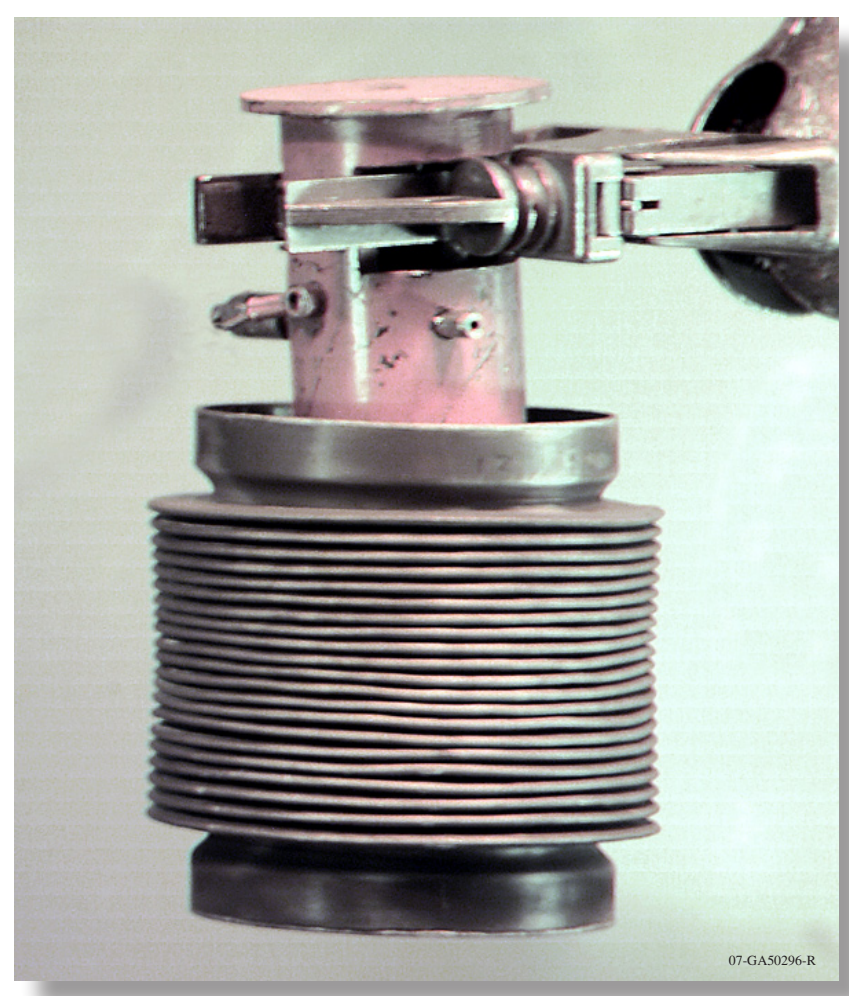

Processed HIP Coil

\begin{tabular}{|l|l|}
\hline \multicolumn{2}{|c|}{ HFEF Non-Destructive Exam Capabilities } \\
\hline Non-Destructive Exams & Equipment Used \\
\hline Neutron Radiography & $250 \mathrm{~kW} \mathrm{TRIGA} \mathrm{Reactor}$ \\
\hline Element/Capsule Diameter Measurements & Element Contact Profilometer (ECP) \\
\hline Element/Capsule Gas Sampling & Gas Assay Sample and Recharge (GASR) \\
\hline Element/Capsule Weight & Element/Capsule Balance (Mettler) \\
\hline Element/Capsule Fission and Activation Product Distribution & Precision Gamma Scanning (PGS) \\
\hline Element/Capsule Bowing and Length & Bow and Length Machine \\
\hline Element/Capsule Visual Exam & Visual Exam Machine (VEM) \\
\hline Macro Photography & High resolution digital photography \\
\hline High precision Specific Gravity measurements & Pycnometer \\
\hline
\end{tabular}




\section{Neutron Radiography \\ Neutron radiography is used for examining internal features of fuel elements and assemblies such as:}

\section{Fuel pellet separations}

- Fuel central-void formation

- Pellet cracking

- Evidence of fuel melting

- Material integrity under normal and extreme conditions

In addition to the examination of individual fuel elements, neutron radiography can also be used for studying the behavior of large test loops or assemblies.

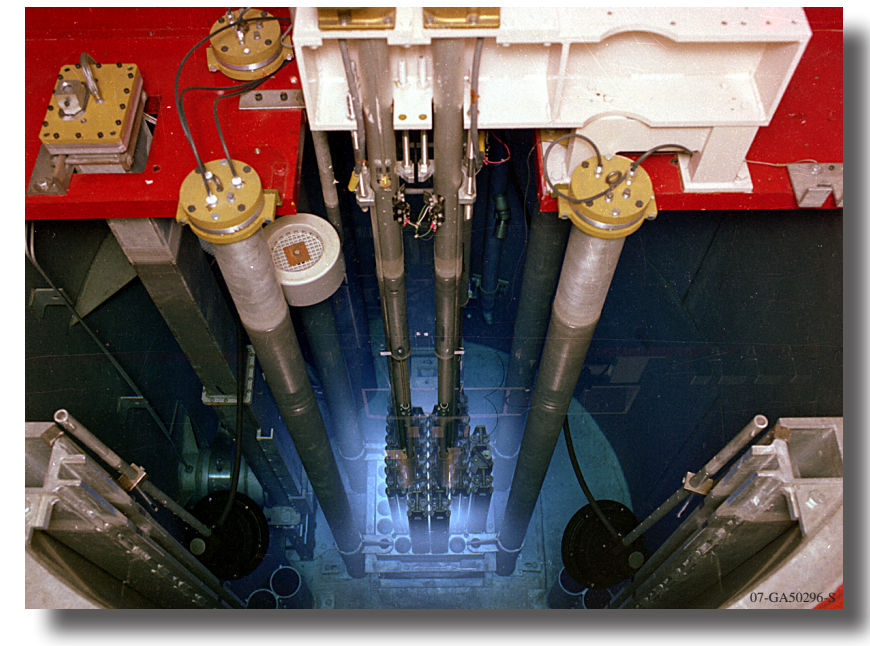

Core of HFEF NRAD TRIGA Reactor

Neutron radiography of elements, capsules and loops is performed in the Main cell at workstation $4 \mathrm{M}$. At the workstation the specimens are placed in a holder which is lowered into the neutron beam in a subcell below the floor of the Main cell. The neutron beam is generated by a $250 \mathrm{~kW}$ Training Research Isotope General Atomics (TRIGA) reactor located below the Main cell. The radiograph holders are designed to position the specimen in the optimum position for radiography without excessive scattering of the neutrons.

Because the intense gamma activity of most irradiated specimens will immediately darken X-ray film, HFEF uses an indirect radiography process. In this process gamma-insensitive neutron detector foils are activated in the neutron beam. Both indium and dysprosium are used as neutron detector foils. These foils are irradiated in the neutron beam then transferred to a film cassette and allowed to decay for three to four half-lives against ordinary X-ray film to form the image. The dysprosium foils are used for thermal neutron radiographs of low enriched fuels and thin structural materials. The thermal neutron radiographs show excellent detail of the specimen. However, because of the lower neutron energies, the specimen thickness and fuel enrichment is limited. The indium foils are used for epithermal neutron radiographs of highly enriched fuels and thicker structural materials. These radiographs do not show the detail of the specimen that is shown in the thermal radiographs but, because of the higher neutron energies, they can be used for thicker specimens and more highly enriched fuel. In many cases, both foils are used to gain an outline of the fuel as well as its internal structure.

The NRAD reactor is also used for a variety of in-core irradiations supporting Laboratory programs, academia, and industry.

Other neutron radiography methods such as Polaroid radiography and track-etch radiography are used for special applications. Polaroid radiographs are made using detector foils having relatively short halflives such as rhodium. These images are made on Polaroid and are almost "instant", requiring about 12 minutes of combined exposure and processing time. The image is of lesser quality but is very valuable in verification of specimen alignment in the beam. 


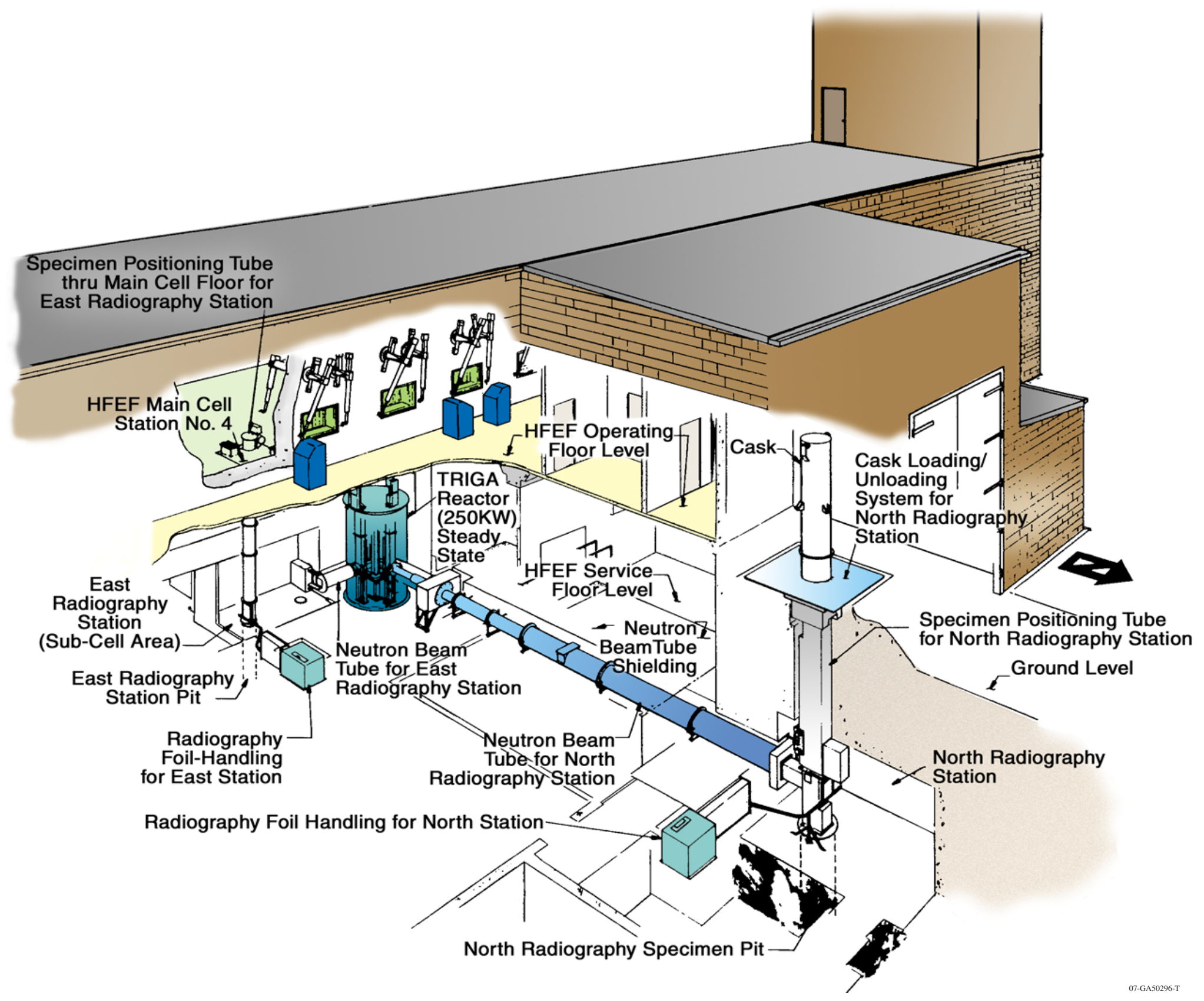

HFEF Neutron Radiography Facility 
Track-etch radiography utilizes a light and gamma-insensitive cellulose nitrate film that can be exposed directly to the neutron beam. A lithiumtetraborate coating on the track-etch film emits alpha particles during neutron radiography which causes microscopic damage tracks in the cellulose nitrate film. The image is enhanced by etching with a sodiumhydroxide solution. Although the resultant image is of extremely low contrast, the resolution is excellent and therefore is of particular value where precise measurements are to be made from the radiographs. A scanning microdensitometer is very useful in evaluating track-etch results.

A Model A-711 MF Physics Corporation neutron generator (14.3 MeV neutrons at $1.0 \times 10^{11}$ neutrons/ sec) has been located in the Nrad north beam tube and supplies neutrons for development of techniques for non-destructive assay of fissionable material waste forms.

The table below shows the system limits for neutron radiography. All of the limits are specified for the east beam tube.

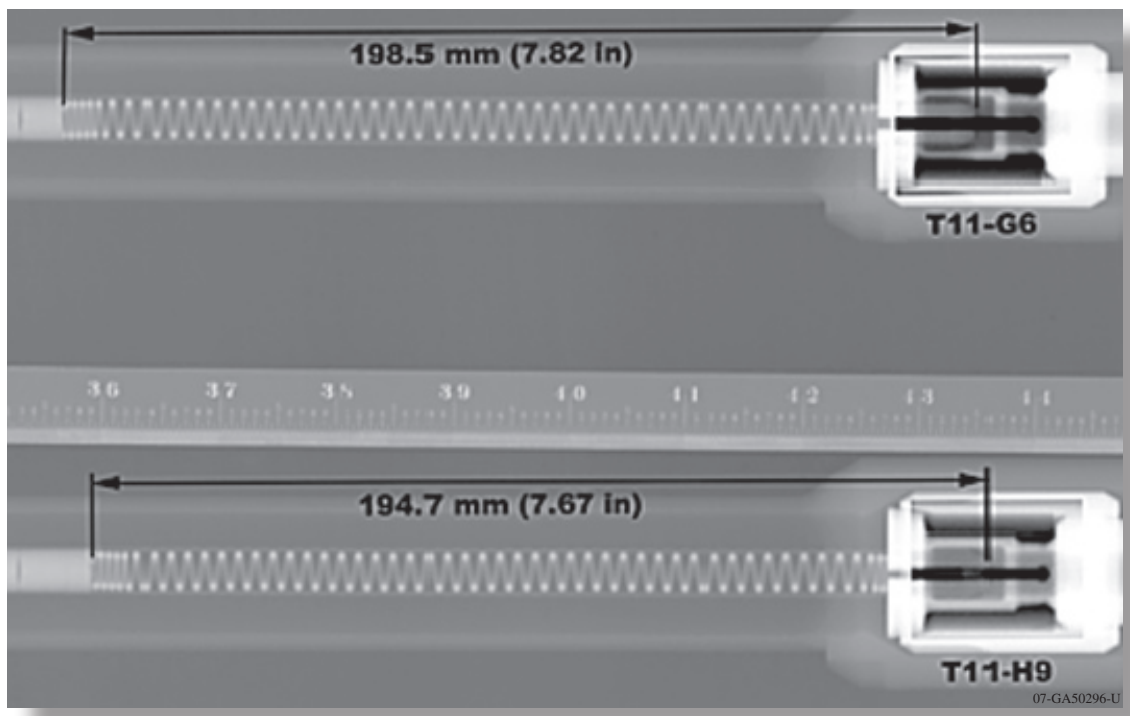

NRAD of PWR Fuel Rods' Plena and Endfittings

\begin{tabular}{|l|l|}
\hline \multicolumn{2}{|c|}{ System Limits for Neutron Radiography } \\
\hline Item & Limit \\
\hline Maximum Specimen Length & 152 in. \\
\hline Maximum Speimen Diameter & 6.5 in. (round) or 4.5 by 8.5 in. (rectangular) \\
\hline Specimen Weigh & 600 lbs \\
\hline
\end{tabular}

\section{Element Handling and Positioning Equipment}

Cylindrical fuel elements and capsules are handled in the Precision Gamma Scanner III, Visual Exam Machine, Element Contact Profilometer, and the Bow and Length machine using element handling equipment. The handling equipment is used to minimize, as much as practical, the handling of the elements and capsules with MS manipulators which reduces the risk of dropping or otherwise damaging the elements during examination. The system allows handling and examination of magazine loads of up to 20 elements and increases the throughput during the examination process. Use of the element handling equipment also allows the safe handling of elements up to $152 \mathrm{in.}$ long.

The element handling and positioning equipment consists of: 1) a heavy duty positioning stage with $\mathrm{X}, \mathrm{Y}$ and $\mathrm{Z}$ motions to position the elements, 2) end fittings for handling the various sized elements and capsules in the positioning stage, 3) an end fitting application station, and 4) cylindrical magazines for storing the elements and placing them in the positioning stage.

The positioning stage consists of a column mounted to a platform carriage. The carriage is equipped with precision motors and lead screws for 
moving the column in the $\mathrm{X}$ and $\mathrm{Y}$ direction. A precision ball screw on the column provides movement in the $\mathrm{Z}$ direction. Mounting surfaces are provided on the $Z$ column and carriage for the attachment of grippers, clamping guides, measuring devices, magazine holders, etc. By making a standard stage with provisions for attaching measuring devices and equipment reduces the inventory of spare parts needed to maintain the stages and makes the equipment more adaptable to changing missions.

Element magazines are held in the positioning stage by a magazine support and positioning fixture attached to the $\mathrm{Z}$ column. The magazine support is equipped with a rotary-drive positive-lock stop mechanism and position indicator. The rotary-drive mechanism is used to rotate the magazines sequentially for element removal and installation. In addition to the rotary-drive, the magazine support is equipped with a linear drive that allows the magazine to be driven laterally over a $14 \mathrm{in}$. range for loading and unloading of the magazines in the support.

Elements or capsules are handled in the positioning stage by an element gripper which provides a positive coupling between the element end fitting and the Z-motion of the positioning stage. The gripper is capable of rotating an element about its longitudinal axis continuously or incrementally. Sensors in the gripper head provide the following indications and measurements:

\section{- The presence of an end fitting within the gripper}

\section{Whether or not the gripper latch mechanism is completely closed}

- Measure of the compressive and tensile forces being exerted on the element

\section{- Location of the top end of the element or capsule relative to a reference $Z$ position}

\section{Indication of the rotation and radial position of the element in the gripper}

End fittings applied to the top of the elements or capsules allow them to be handled by the gripper head. The end fittings are modified lathe collets attached to the elements or capsules at an application station. A horizontal orientation pin in the top of the end fitting is used to tighten or loosen the threaded collet onto the element or capsule and provides angular reference indication. A changeable push rod in the center of the end fitting is used to provide indication of the element's position with respect to a referenced $\mathrm{Z}$ and to provide indication of the compressive and tensile forces on the element. The push rod is captured inside the end fitting but it is free to move longitudinally so it can provide indication of the insertion depth of the element within the end fitting. The top of the push rod mates with a sense rod inside the gripper head to provide both force and position information on the element.

The end fittings are applied to the elements in an end fitting application station located on the north side of the Main cell at workstation $4 \mathrm{M}$ or elsewhere using a portable endfitting station. The end fittings are applied to the element by inserting the end fitting in the applicator head and then inserting the element in the end fitting. Both of these operations are performed using MS manipulators.

Once the end fittings are installed on the elements or capsules, they are stored in an element magazine. The element magazines are cylindrical containers with sockets around the inside perimeter at the top. A slot on the outboard side of each socket is used to orient the element in the magazine using the orientation pin on the end fitting. When the end fittings are installed on the elements, the plane of the bow of the element is aligned with the orientation pin with the bow facing away from the pin. When the elements are placed in the magazine the bow faces the center of the magazine. During examination of the element, the $\mathrm{Z}$ column of the stage is moved so the element is near the center of the magazine. In this way the element cannot touch another element or the magazine during the examination.

The following table lists the parameters and capabilities of the element handling equipment. 


\begin{tabular}{|l|l|}
\hline \multicolumn{2}{|c|}{ Element Handling Equipment Parameters and Limits } \\
\hline Parameter & Value \\
\hline Total Vertical Travel & 139 inches \\
\hline Fast Vertical Speed & Variable 18 to $30 \mathrm{in} . / \mathrm{min}$. max. \\
\hline Slow Vertical Speed & Variable 0 to 6 in. $/ \mathrm{min}$. max \\
\hline Vertical Step Travel & $0.001 \mathrm{in} . / \mathrm{step}$ \\
\hline Lift Force & $3000 \mathrm{lb}$ max. \\
\hline Positioning Repeatability & $+0.005 \mathrm{in}$. \\
\hline
\end{tabular}

\section{Precision Gamma Scanner}

The fission and activation-product activity distribution in fuel elements or capsules can provide valuable information on how the component was affected both in the reactor and during subsequent storage. The Precision Gamma Scanner (PGS) is used to measure this activity as a function of position in the component. These activity measurements can provide:

- Relative fuel burnup and power profiles of reactor fuels

- Structural activation profile of core components

- Position and dimension of internal structures within fuel assemblies

- Relative distribution of various isotopes of interest in fuel

- Identification of breached elements or capsules

The gamma scanner can be used for scanning large components such as test loops, as well as reactor components and fuel

elements. The scanner uses a standard element handling stage for positioning the component in front of a collimator, a collimator for shaping the gamma beam, a detector and its associated electronics for detecting the gamma radiation and dividing its spectra into individual energies, and a computer for operating the stage and processing the spectral data.

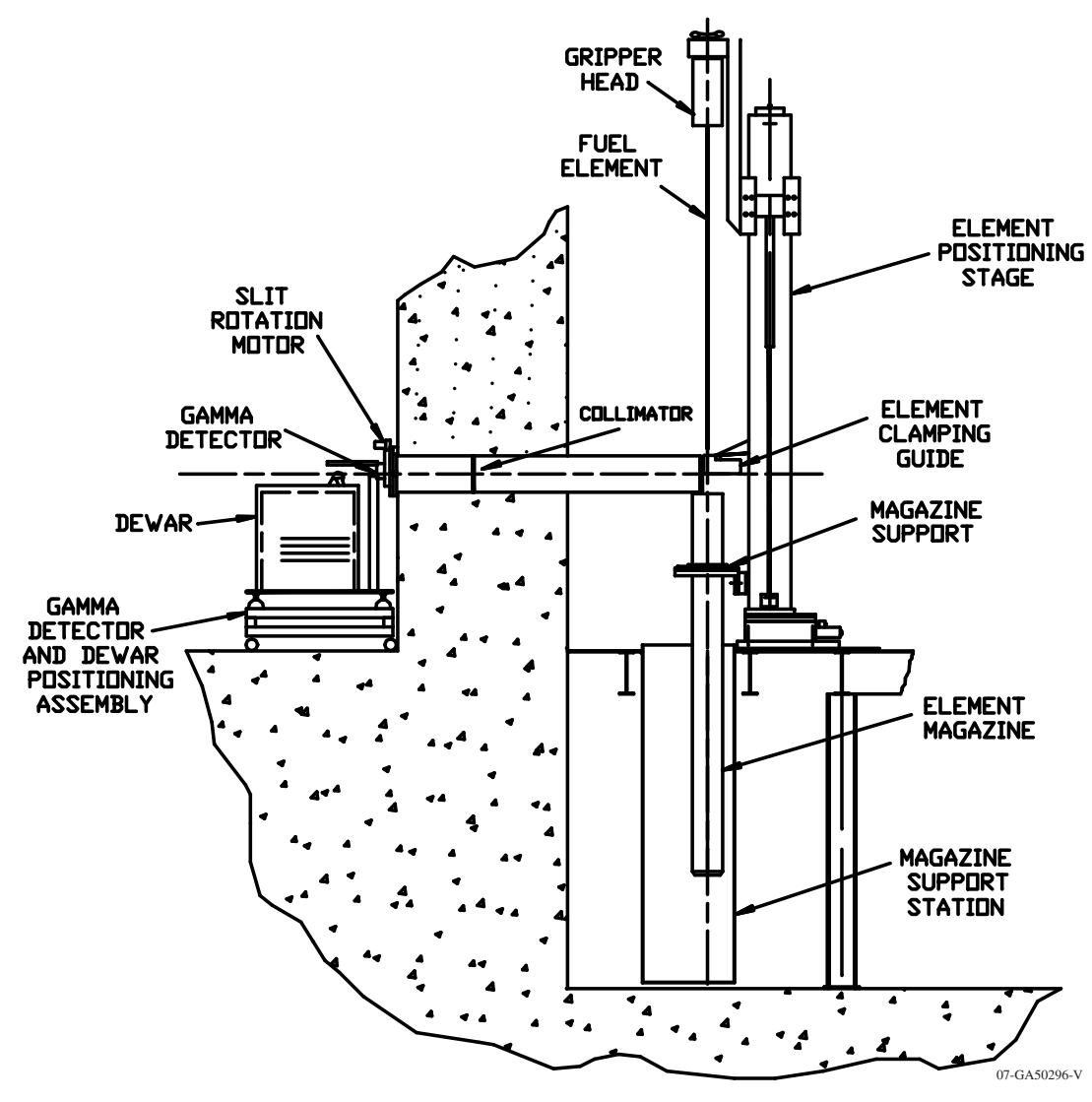


The stage for positioning the elements has four degrees of freedom. Components being examined can be moved parallel to the cell wall, perpendicular to the cell wall, vertically. or rotated as needed to position an area of interest in front of the collimator. The collimator has a rectangular slit having an adjustable slit width. By varying the slit width, the count rate to the detector can be held below the saturation rate for the system. The detector is a solid germanium crystal surrounded by a sodium-iodide (NaI) crystal. The $\mathrm{NaI}$ detector is used for removal of the Compton background to improve the statistical confidence in the data.

\section{Two types of gamma scans are generally performed:}

Gross gamma scans, and

- Isotopic gamma scans

Gross gamma scans are used to determine the distribution of activity over the component's length or width. In this scan, the component is traversed in front of the collimator and the total gamma count rate is measured without regard to the energy of the gamma rays. The data is presented as a plot of the count rate versus the component's position.

In the isotopic gamma scan, the component is also traversed in front of the collimator and the count rate measured as in the gross scan; but the data in the isotopic scan is broken down into individual energies and the corresponding isotopes are identified. This data is presented as a plot of the isotopic activity versus the component's position. The isotopic gamma scan is used to determine the isotopic distribution of activity over a component's length or width. HFEF has an extensive isotope library that can be expanded to meet a user's particular needs.

The Gamma Scanner system limits are shown in the table below.

\begin{tabular}{|l|l|}
\hline \multicolumn{2}{|c|}{ Gamma Scanner Limits } \\
\hline Parameter & Limit \\
\hline Maximum Count Rate & $86,000 \mathrm{cps}$ \\
\hline Maximum Weight & $500 \mathrm{lb}$ \\
\hline Slit Dimensions & 0.875 -in. long by 0 to 0.099 -in Wide \\
\hline Maximum Vertical Travel & 152 in. (nominal) \\
\hline
\end{tabular}




\section{Element Contact Profilometry}

The Element Contact Profilometer (ECP) is a continuous-contact profilometry gauge for measuring axial and spiral diameter profiles of elements and capsules. Horizontally-opposed linear transducers contact the element as it is pulled vertically through sapphire-tipped probes. Guide rollers positioned above and below the transducers maintain the element vertical with respect to the transducers.

Measurement range is designed for element diameters between $0.174 \mathrm{in}$. and $0.840 \mathrm{in}$., having a maximum diametral swelling of $0.02 \mathrm{in}$. The swelling range is limited by the linearity of the probes for the size of elements being handled. Certified calibration standards for each element size are used for zero, mid-span, and full-span calibration. Measurement accuracy through this range is within $3 \times 10^{-4}$ in. $\left(7.6 \times 10^{-3}\right.$ $\mathrm{mm}$ ) nominally. Data output of the element profile is in the form of a Microsoft Excel file and paper strip chart. The data is furnished to the experimenter on a compact disk. The table below lists the measurement range and accuracy of the ECP.

\section{ECP Range and Accuracy Measurement Range and Accuracy}

Element/Capsule Diameters - 0.174 in. to $0.840 \mathrm{in}$.

Demonstrated accuracy within 0.0003 in. of Actual

Diametral Swelling

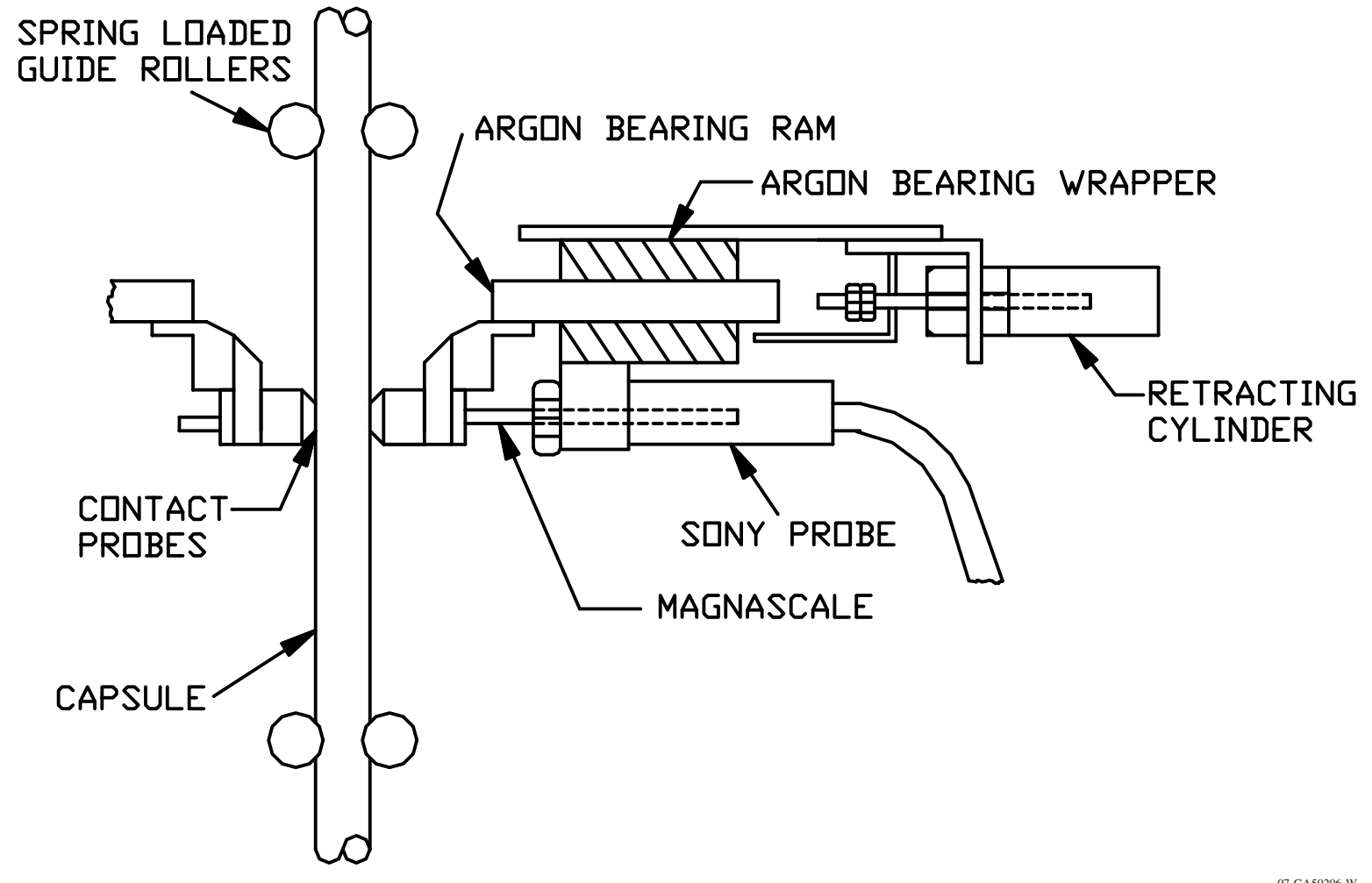




\section{Gas Assay Sample and Recharge (GASR)}

The Gas Assay Sample and Recharge System (GASR) provides the ability to puncture cylindrical capsules or fuel elements in their plenum regions to measure the free volume and pressure and to gather a sample for gas composition and isotopic analyses. After puncturing and measuring an element's pressure and volume, it may be refilled with any specified gas and rewelded. Although this weld is primarily for contamination control and not for in-reactor service, the welds that have been made are well characterized and have been tested to 100 psia. Reactor quality welds could be produced with further characterization. The system provides volume and pressure data to within $\pm 5 \%$ on capsules in the pressure - volume range of 0.03 to 60 liter-atmosphere. This wide range is accomplished by use of auxiliary calibrated volumes within the system. Other volumes and pressures can be accommodated by the system through appropriate system adjustments. The system is comprised of a $150 \mathrm{~W}$ pulsed laser, shielded optical and gas cell-wall feed-through, a mechanical pump, calibrated volumes, gages and controls. Operational sequences are fully interlocked to prevent improper valve or laser operations. The fuel elements or capsules are positioned on the laser by a clamp onto a neoprene gasket. The gasket provides a seal between the element and laser seal head. System limits and information on the GASR are provided in the tables below.

\begin{tabular}{|l|l|}
\hline \multicolumn{2}{|c|}{ GASR Limits and Capabilities } \\
\hline Parameter & Limit \\
\hline Element Diameter Range & 0.174 to 0.832 in. \\
\hline Element Length Range & 1 to 152 in. \\
\hline Cladding Thickness & 0.010 to .125 in.* \\
\hline Observed Accuracy & $\begin{array}{l}\text { Better Than } \pm 5 \% \text { for Pressure } \\
\text { and Volume }\end{array}$ \\
\hline $\begin{array}{l}\text { * Thicker walled cladding can be punctured } \\
\text { by mechanically thinning the cladding in } \\
\text { the puncture area. }\end{array}$ \\
\hline
\end{tabular}

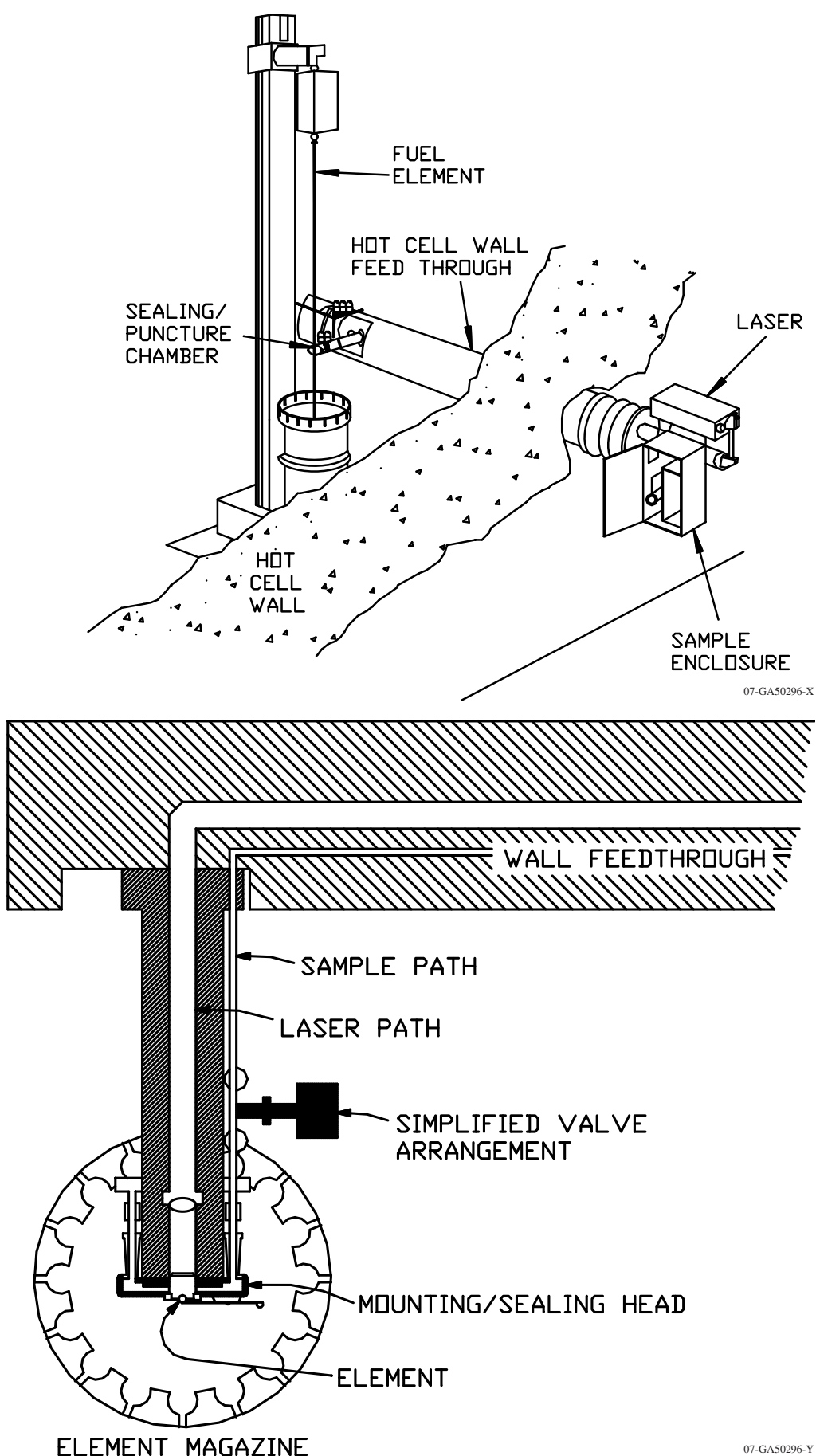


Hot Fuel Examination Facility

\begin{tabular}{|l|l|}
\hline \multicolumn{2}{|c|}{ Laser Specifications } \\
\hline Type & Neodymium - YAG \\
\hline Maximum Energy per Pulse & 20 Joules \\
\hline Rated Average Power & $150 \mathrm{~W}$ \\
\hline Pulse Repetition Rate & 1 to 150 pulses per second (pps) \\
\hline Beam Width & 0.25 in. \\
\hline Final Lens Focal Length & 4 in. \\
\hline Minimum Spot Diameter & $\sim 0.005$ in. \\
\hline
\end{tabular}

\begin{tabular}{|l|l|}
\hline \multicolumn{2}{|c|}{ Pressure and Vacuum Instrumentation } \\
\hline Sealing Head Pressure & 10 to $200 \pm 0.1 \mathrm{psia}$ \\
\hline Manifold Pressure & 0 to $50 \pm 0.01 \mathrm{psia}$ \\
\hline Manifold Vacuum & 1 atm to 10 millitorr \pm 5 millitorr \\
\hline Sample Line Vacuum & 1 atm to 10 millitorr \pm 5 millitorr \\
\hline Sample Line Pressure & 0 to $50 \pm 0.01$ psia \\
\hline
\end{tabular}

\section{Bow and Length Machine}

The element bow and length machine is used to measure the distortion (bow) and actual length of irradiated cylindrical fuel elements and capsules. The machine can be used to determine the fuel element or core component's length and bow as well as the direction of the plane of the bow.

The bow and length machine is a standard element handling stage equipped with a set of perpendicular bars. The bars are driven by lead screws and the element or core component's bow is measured by the position of the bars with respect to the axis of rotation. In order to prevent the bars from disturbing the element during the measurement, they are equipped with light sensors. When the element or component breaks a beam of light, the drive on the bars is stopped. Encoders on the bar's lead screws convert the position of the bar into an $X-Y$ coordinate pair. The $X$ axis of the Cartesian coordinate system runs parallel to the cell wall. The $Y$ axis of the system runs perpendicular to the wall. The $\mathrm{Z}$ axis is vertical. Measurements are made at various positions along the length of the component by incrementally moving the component past the bars. 
At each measurement position, the $\mathrm{X}, \mathrm{Y}$ and $\mathrm{Z}$ positions are recorded. The element or component's bow is determined by calculating a tipto-tip centerline, then calculating a perpendicular distance from this centerline to the element's actual centerline. The direction of bow is calculated from the information used to calculate the magnitude of the bow. These calculations are performed at each location measured along the axis of the element or component.

To determine the element or component's length and the tip-totip centerline, the axial position of the bottom tip of the element is measured by lowering the element or component until the bottom tip contacts a pad on the X-position bar. From the indications provided by the machine, and from data obtained from a length standard, the axial position of the top end of the element or component

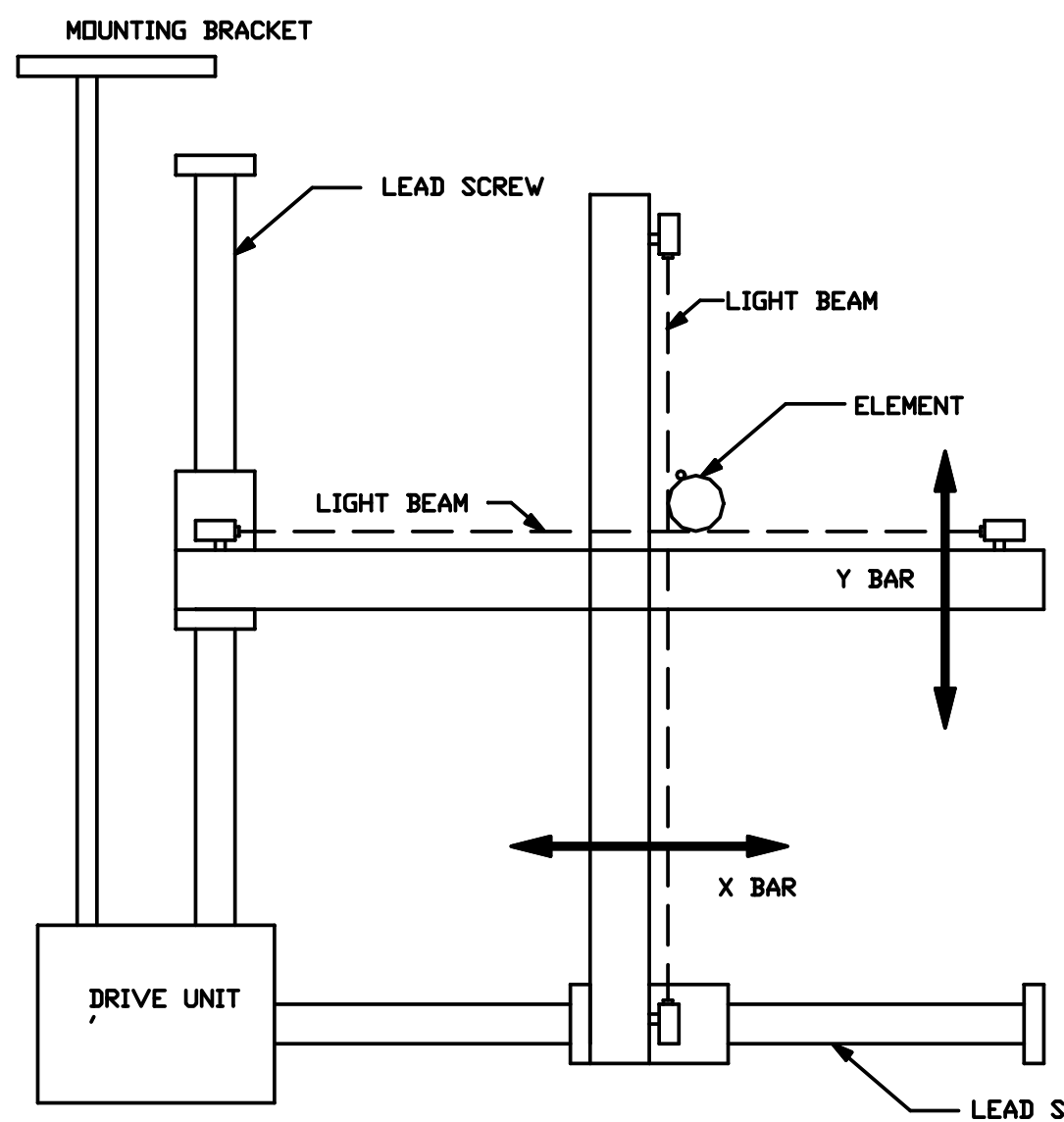

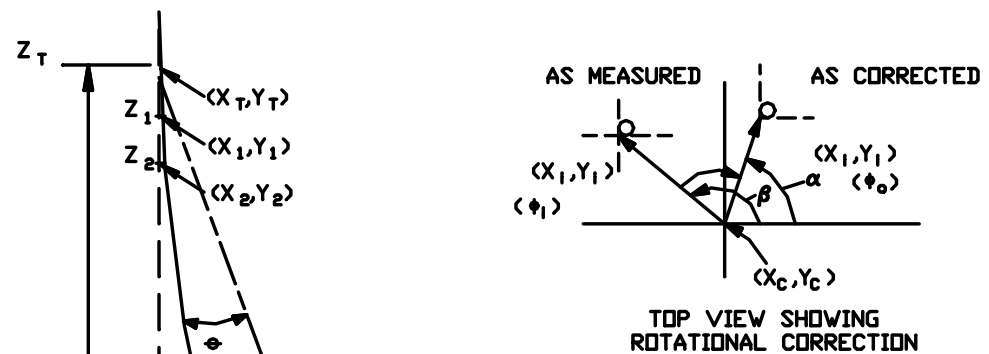

TUP VIEW SHDWING
RDTATIONAL CDRRECTION

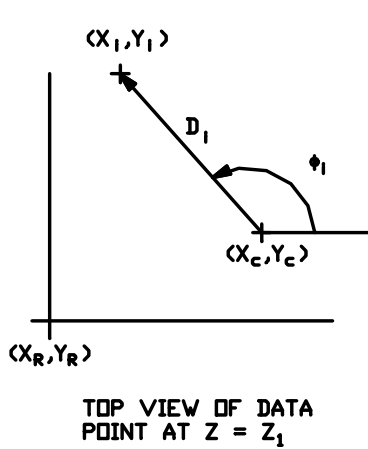

is calculated. The $X$ and $Y$ coordinates of the ends of the element or component are determined by extrapolating the top and bottom two measured points and the calculated end points. The element's free hanging length is determined by summing the chord lengths. Bow measurements of elements or components that have spacer wires are taken in a plane away from the wire. This prevents the wire from breaking the light beam and causing a false reading. 
The data from the bow and length measurements is presented in the form of tables giving the element number, the bow. and the angle in which the bow occurs. In addition, the data is summarized into two tables. The first of these tables summarizes the bow data and gives the element number, the maximum bow, and the angle of bow. The second table gives the element's corrected hanging length. The limits for the Bow and Length Machine are given in the table below.

\begin{tabular}{|l|l|}
\hline \multicolumn{2}{|c|}{ Bow and Length } \\
\hline Item & Limit \\
\hline Element/Capsule Length & 18 to 139 in. \\
\hline Element/Capsule Diameter & 1 in. max \\
\hline Accuracy of Bow Measurements & 0.020 in. \\
\hline Accuracy of Length Measurements & 0.010 in. \\
\hline
\end{tabular}

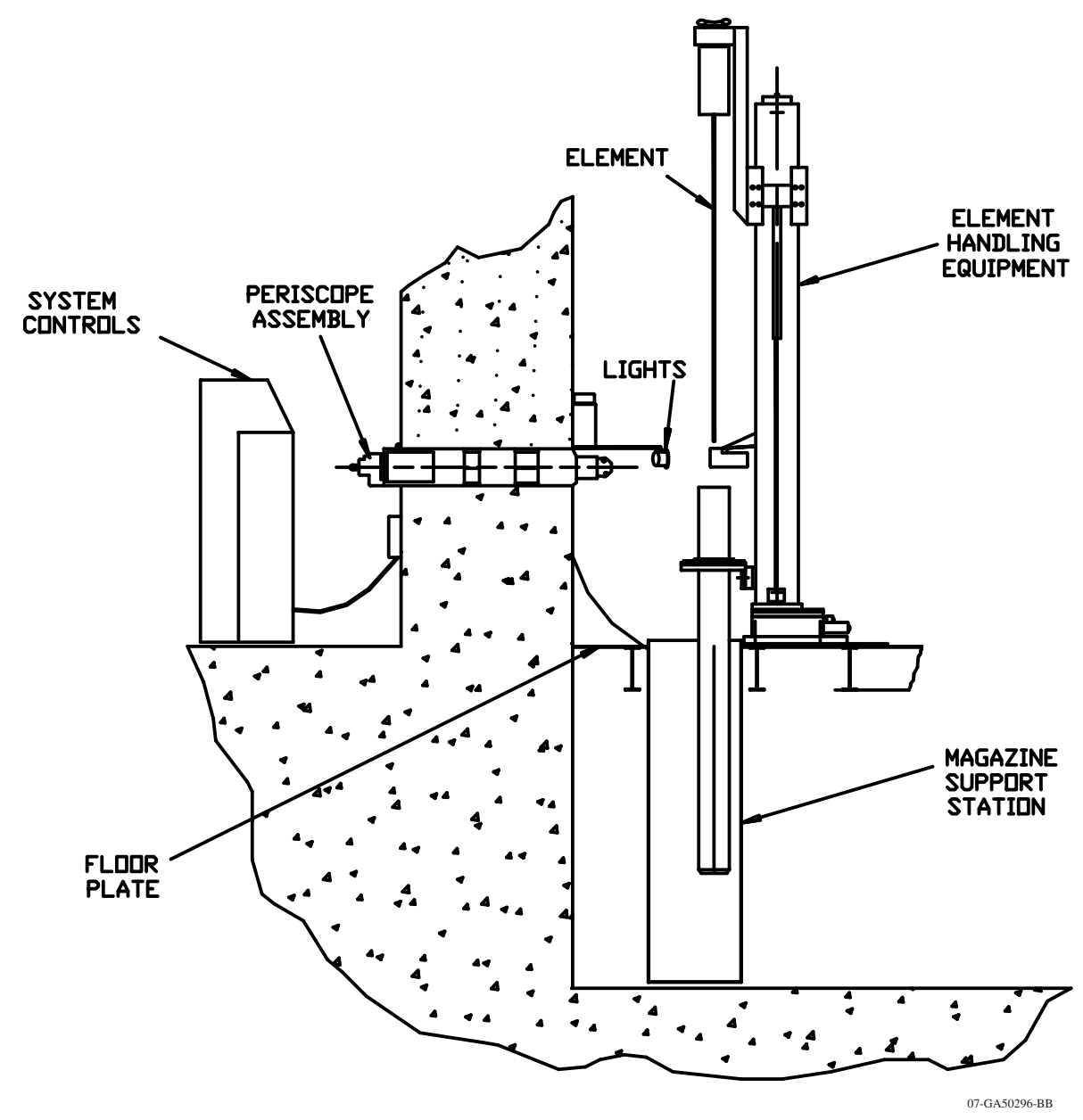

\section{Visual Exam Machine (VEM)}

The VEM provides a dedicated workstation for performing visual examination on fuel elements, capsules and other irradiated items. The VEM consists of a standard in-cell examination stage and a modified Kollmorgan throughwall shielded periscope. It is designed for full-surface inspection and photo-documentation of irradiated fuel elements or capsules. The VEM has been equipped with a pair of commercial photographic strobe lights with builtin halogen modeling lamps. The strobe lights are used exclusively for photography, while the modeling lights, whose intensity is adjustable, are used for both viewing and photography. To help define the edges of objects being examined, a neutral-colored (gray) background panel is located behind the object. This panel is embossed with a dimensional grid for aligning the periscope and object being viewed at low magnification. 
The Kollmorgan periscope provides controls for aiming the objective (i.e., pointing the line-of-view), selecting among three magnifications, and focusing the image. The standard (spherical) optics of the periscope have been replaced with special planar optics that maintain the entire surface of a flat object (oriented normal to the optical axis of the system) in focus at the film plane.

The periscope is equipped with three levels of optical magnification. They are labeled " $4 x^{\prime \prime}$, " $10 x^{\prime \prime}$, and " $25 x$ " to correspond to their nominal angular magnifications. The actual image magnification achieved depends on the angular magnification, the distance to the object, the camera used and, when used, the photo-print enlargement.

The periscope is equipped with a standard Kollmorgan camera with a 4"x5" Grafflex film holder. Recently a digital high resolution Leaf Volare camera body has been adapted to mount to the Kollmorgan camera port in place of the standard Kollmorgan camera. This camera is also used to perform composite photography through the cell window as well as standard through-the-window characterizations and provides output in most common digital formats.

\section{Destructive Examination Equipment}

HFEF has destructive examination capabilities useful for general characterization of spent nuclear fuel and other irradiated materials. The following table lists the destructive examinations and the equipment used to perform the examinations. Brief descriptions of the equipment are given in the sections below.

\begin{tabular}{|l|l|}
\hline \multicolumn{2}{|c|}{ HFEF Destructive Exam Capability } \\
\hline Destructive Exams & Equipment Used \\
\hline Sample Cutting and Preparation & Containment Box in Main Cell Zone 2M \\
\hline Mounting Samples in Metallographic Mount & Containment Box in Main Cell Zone 2 M \\
\hline Fuel Sample Visual Exam and Photography & Leitz Metallograph in Met Box \\
\hline Detailed Photography of Sample & High Resolution Digital Photography \\
\hline Scanning Electron Microscopy & (SEM) in Met Box \\
\hline Microhardness & Leitz Metallograph in Met Box \\
\hline Punch Samples TEM Sample Preparation & Subassembly Hex-Can Punch/sample thinning Zones 3M and 2M \\
\hline
\end{tabular}




\section{Containment Box}

Irradiated fuel, cladding and structural materials are sectioned, mounted into metallographic (met) mounts, ground and polished in the containment box located in the HFEF Main cell. The containment box is sealed to the cell wall near the north-west corner of the Main cell and has its own argon atmosphere and atmosphere control system. The box is separated from the rest of the Main cell to prevent the spread of alpha contamination to the cell and to keep etchant and cutting fluid vapors used in the preparation of metallographic samples from contaminating the argon atmosphere of the Main cell. Via pneumatic transfer (rabbit), the samples thus prepared are transferred to the Met Loading Box for electron or light microscopy.

\section{Metallographic Loading Box, Leitz Metallograph and Amray Scanning Electron Microscope}

The Leitz metallograph is located in the Metallographic Loading Box (Met Box) on the north side of the HFEF Main cell. The Met Box is a lightly shielded ( 8 " lead brick sides and back by $15^{\prime \prime}$ steel front) containment box with an argon or nitrogen atmosphere and atmosphere control system whose function is to allow detailed examination and photomicrographs of irradiated samples. Irradiated samples prepared in the containment box are pneumatically transferred to the Met Box where they are examined by either the Leitz metallograph or the Scanning Electron Microscope (SEM). On the east end of the Met Box is the Leitz metallograph. On the west end of the box is the SEM. A shielding window with two CRL model L master/slave manipulators are located on the south face of the box for handling the samples within the box.

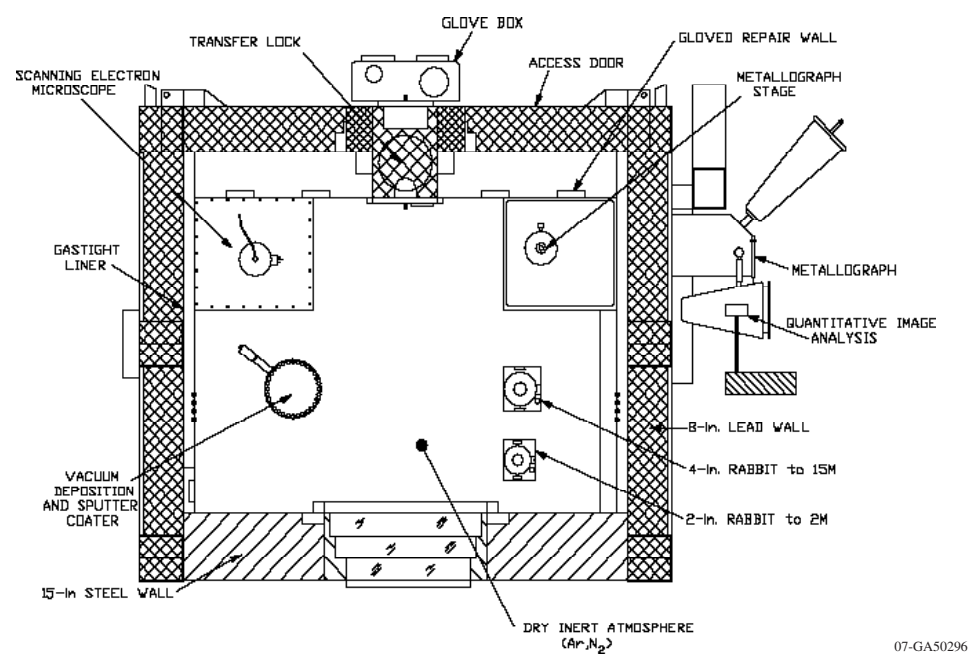

The Leitz metallograph is used to perform microscopic examination, photography and microhardness testing on metallographic samples. It is designed for remote operation with the stage inside the met box and the operating controls outside the box. The metallograph is also equipped with a Vickers-type diamond indenter hardness tester, a projection screen and both low-voltage tungsten and xenon lights. The tungsten lights are for general viewing while the xenon light is for detailed viewing. Samples placed under the microscope can be viewed by either the projection screen, an eyepiece, or photographed using a 4 in. by $5 \mathrm{in}$. bellows-type camera.. The camera has a rotating back with ground glass screen and can accommodate either Polaroid or cut film.

The operating limits for the Leitz metallograph are given in table below.

\begin{tabular}{|l|l|}
\hline \multicolumn{2}{|c|}{ Leitz Netallograph Limits } \\
\hline Item & Limits \\
\hline Magnification Range of Microscope & $20 \mathrm{X}$ to 800X \\
\hline Hardness Tester Magnification & $400 \mathrm{X}$ \\
\hline Minimum Hardness Tester Weight & $5 \mathrm{gm}$ \\
\hline Maximum Hardness Tester Weight & $400 \mathrm{gm}$ \\
\hline
\end{tabular}




\section{Shielded Scanning Electron Microscope (SEM)}

The shielded AMRay 1200 B SEM is located in the north-west corner of the met box and is used for material characterizations such as fractures, wear surfaces, or other applications where sample topography is needed. Both radioactive and non-radioactive materials can be examined with this unit.

\section{Shielded Scanning Electron Microscope Limits}

Magnification 15X to 30,000X

Specimen Size 1.5 in. by 1.5 in.

\section{Transmission Electron Miscroscopy Sample Preparation Equipment}

A special device has been designed to obtain samples of thin-walled (less than 80 mils thick) metallic components for characterization such as immersion density, microscopy, chemical analysis, etc. The hex-can punch is used primarily for punching 1 in. diameter sample disks from the stainless steel hex ducts on subassemblies. The device can be used on any other thin-walled metallic component as long as it is relatively flat so it can fit under the punch assembly.

The hex-can punch consists of a standard $1 \mathrm{in}$. diameter punch and die set driven by an ENERPAC ${ }^{\mathrm{TM}} 10$ ton hydraulic press unit. The punch is entirely self-contained, sitting on a base which contains the hydraulic fluid reservoir and electric pump. The punch and die set and hydraulic cylinder are mounted to a frame which is mounted to the base. The unit is portable and it can be moved to different locations in cell as needed.

\begin{tabular}{|l|l|l|}
\hline \multicolumn{3}{|c|}{ Major Upgrades And Enhancements } \\
\hline Upgrade & Date & Purpose \\
\hline $\begin{array}{l}\text { 250-kW Neutron Radiography Facility } \\
\text { and Darkrooms }\end{array}$ & 1978 & $\begin{array}{l}\text { Specimen imaging and characterization with 250-kW TRIGA-FLIP reactor Neutrons are } \\
\text { superior to X-rays for high atomic weight elements }\end{array}$ \\
\hline $\begin{array}{l}\text { Second Neutron Radiography Beam and } \\
\text { Radiography Station }\end{array}$ & 1984 & $\begin{array}{l}\text { Highly collimated beam provides high resolution radiographs for irradiated unirradiated } \\
\text { materials without having to insert the specimens into the cell }\end{array}$ \\
\hline Examination Stage Extensions & 1985 & Allows examinations of elements/rods to 10' \\
\hline Shielded Scanning Electron Microscope & 1984 & Heavily shielded electron microscope for surface and microstructural characterizations \\
\hline Examination Stage Extensions & 1998 & Allows examinations of elements/rods to 12' \\
\hline Digital Photography & 1999 & $\begin{array}{l}\text { Upgrade of through-the-window and Periscope photo-documentations Eliminates the } \\
\text { burden of wet chemistry photo-processing }\end{array}$ \\
\hline
\end{tabular}




\section{SUMIMARY AND A LOOK TO THE FUTURE}

The Hot Fuel Examination Facility is widely considered one of the "crown jewels" of the Battelle Energy Alliance facilities supporting the nation's nuclear research and development at the Idaho National Laboratory. National attention has returned to nuclear energy through the Global Nuclear Energy Partnership (GNEP) and the Next Generation Nuclear Plant (NGNP) initiatives. Funding has been identified to re-establish and maintain HFEF's state-of-the-art post-irradiation examination capabilities. Updates or replacements to such systems as the Neutron Radiography, Gas Sample Assay and Recharge, Gamma Scanning, and Metallography systems have been identified, and prioritized, and new capabilities are being designed for installation and operation in support of GNEP, NGNP and other programs.

HFEF continues to support long range high-payoff engineering research and development in the conditioning of spent fuels and materials, via participation in the Advance Fuel Cycle Initiative. On-going work within the AFCI includes an International Nuclear energy Research Initiative (I-NERI) project between Korea Atomic Energy Research Initiative and the INL to research the electrolytic reduction of advanced oxide fuels in HFEF's Hot Fuel Dissolution Apparatus.

Participation continues in the National Nuclear Security Administration (NNSA) and Defense Threat Reduction Administration (DTRA) programs, with training and exercises hosted periodically in the facility, along with innovative and unique demonstrations of the application of post-irradiation examination technologies to national defense exercises.

In the recent past HFEF has expanded its cask-handling abilities to include the Trans-Nuclear Fort St. Vrain cask as well as the GE 100 and GE 2000 casks. This expansion of cask handling capabilities represents a sizeable commitment to the support of commercial nuclear industry PIE needs, to the research and development community with experiments coming from the Advanced Test Reactor also located at the Idaho National Laboratory.

HFEF's status as a world-class post-irradiation examination facility continues as it grows its suite of radioactive fuels and materials handling and examination capabilities. Its favorable situation enables it to service DOE, commercial, private, proprietary and classified programs with appropriate data and material protection and discretion along with its unique set of capabilities ensures its preeminent place in the world of nuclear fuels and materials research and development. 


\section{Contacts:}

Richard S. Cain, Manager

Hot Fuel Examination Facility

Idaho National Laboratory

P.O. Box 1625

Idaho Falls, Idaho 83415-6166

(208) 533-7628

Gary R. Tarbet, Manager

Hot Cell Services

Idaho National Laboratory

P. O. Box 1625

Idaho Falls, Idaho 83415-6166

(208) 533-7448 


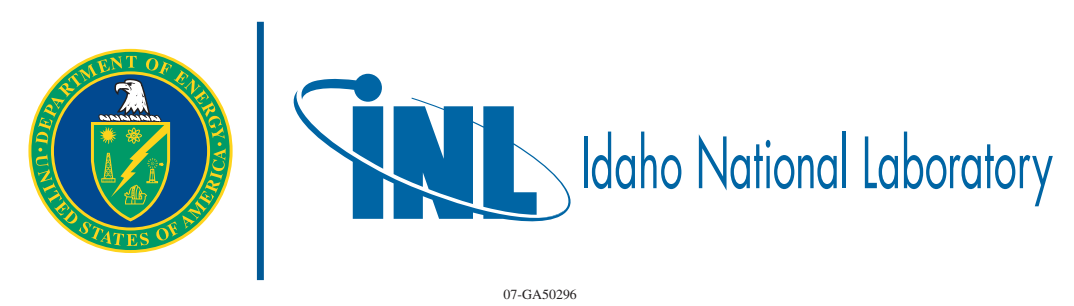

